DEPARTMENT OF THE INTERIOR

UNITED STATES GEOLOGICAL SURVEY

GEORGE OTIS SMITH, DIRECTOR

\title{
BuLletin 615
}

$$
\text { A NOELLED }
$$

\section{RHODE ISLAND COAL}

BY

GEORGE H. ASHLEY

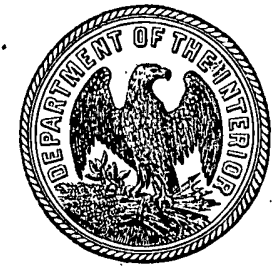

WASHINGTON

GOVERNMENT PRINTING OFFIOE 
$r$

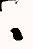

r

$r^{3}$

r

$-\therefore$

P

$\square$

-

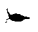

。

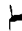

$-$

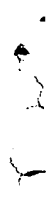

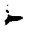

2 


\section{CONTENTS.}

-

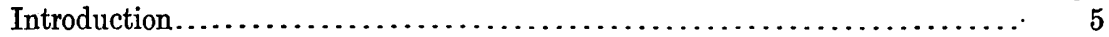

History of development and use of Rhode Island coal . . . . . . . . . . . . . 7

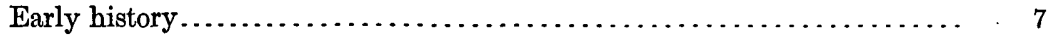

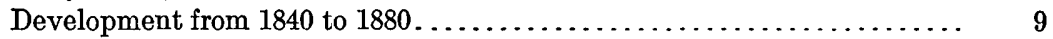

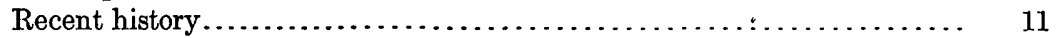

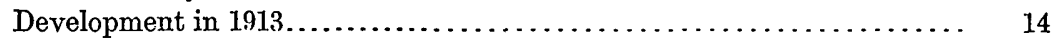

Conditions affecting method and cost of mining.................... 14

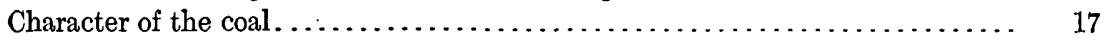

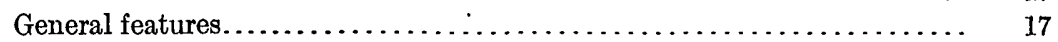

Field conditions........................................... 17

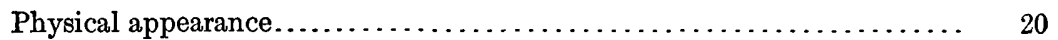

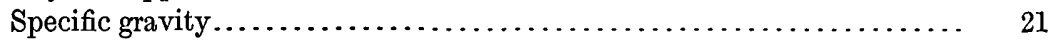

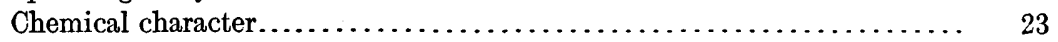

Reason for low heat value of Rhode Island coal................. 33

Behavior of Rhode Island coal toward moisturc ................. 37

Utilization of Rhode Island coal............................... 38

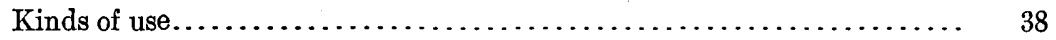

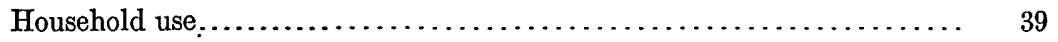

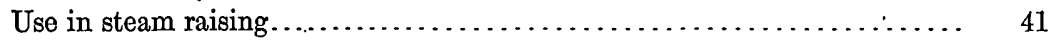

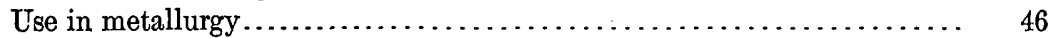

Briquetting tests.......................................... 47

Brick burning and similar work............................ 48

Indirect use as water gas or producer gas......................... 49

Use for foundry facings and furnace linings.................... 57

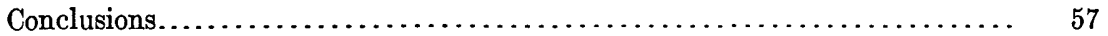

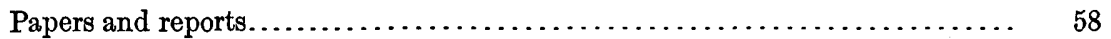

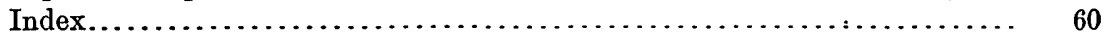

\section{ILLUSTRATIONS.}

Plate I. Sketch map of the Rhode Island coal field ..................

II. Views at Budlong mine, Cranston, R. I.: $A$, Open cut in mine, looking north; $B$, Face of bed a little north of the mouth of the slope, showing the characteristic schistose or squeezed-lens appearance of the coal

III. $A$, Surface plant at Budlong mine, Cranston, R. I.; $B$, Surface plant at South mine of Portsmouth Coal Co., Portsmouth, R. I.........

IV. $A$, View in graphite mine at Fenners Ledge, near Providence, R. I.; $B$, Diagram showing distortion of the bed represented in $A \ldots \ldots$.

V. $A$, View at north end of Budlong pit, Cranston, R. I.; $B$, Diagram showing variations in thickness of anthracite at north end of Bud-

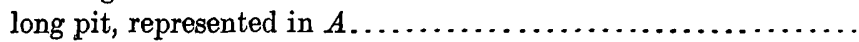

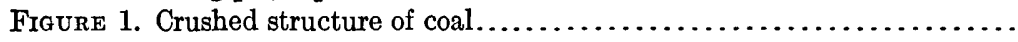

2. Chart showing composition and theoretic heating power of Rhode Island coal in comparison with other coals with which it must compete in New England.

3. Chart showing relation of carbon in Rhode Island coal to fuel value.. 


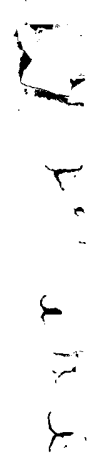

$r$

6

$\zeta$

6

1

$\Gamma$

r

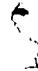

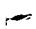

r $-$ 


\title{
RHODE ISLAND COAL.
}

\author{
By George H. Ashley.
}

\section{INTRODUCTION.}

Rhode Island coal has had a perennial interest for the people of that State and for outside coal and iron men and promoters. Its situation, directly on the seaboard and in the center of a region of dense population and large manufactures (see PI. I), gives it a great advantage in the New England markets over other coals through reduced cost of transportation, an item that adds largely to the cost of the coals with which New England is now supplied. Lured by this apparent advantage, company after company has sought to exploit the coal or to utilize it in metallurgic enterprises in which they were interested; but the fact remains that Rhode Island anthracite is still unused commercially and the impression has become general that, considered as a source of heat, it is more of a will-o'-the-wisp than a reality.

On the one hand, it is contended that in the final great conflagration Rhode Island coal will be the last thing to take fire. On the other hand, it is said that for more than 20 years the Taunton Copper Co. used this coal exclusively and successfully for fuel. Both these statements can not be correct, so to meet the demand arising from many inquiries made of the Survey for some definite statement of facts in regard to Rhode Island coal, the author spent a few days in the first part of October, 1913, in Rhode Island studying the mining and use of the coal, and by means of the results of those studies and other data, already published, has prepared the following brief paper describing the coal, its use, and its mining. The geology of the Rhode Island coal field, at least of that part of it which is in Rhode Island, will be described in a detailed State report, now in preparation by Charles W. Brown, State geologist of Rhode Island.

The facts ascertained and here reported may be briefly summed up as follows:

The coal of Rhode Island is extremely variable in character and quality, ranging from anthracite to graphite, and containing moderately high ash to very high ash, and usually a high percentage of moisture when first mined. Because of its peculiar characteristics, all the coal requires peculiar handling to be used successfully, and the extremely 
graphitic portions can hardly be used as fuel. The attempt to burn it or to treat it as other coals have been treated has usually been unsuccessful, but if properly prepared and properly used, it appears to have possible uses. Its high content of water requires that it be seasoned under cover before it is used, and its commonly high content of ash is adverse to its shipment for use at distant points. Its greatest future use, therefore, appears to be at the mines in the manner indicated in this report.

The coal beds appear to have been originally of moderate thickness, but they have been folded, compressed, and squeezed by pressure until the coal has been forced into great pockets in places and nearly or quite squeezed out elsewhere, the beds as a whole dipping into the earth irregularly and at high angles. On account of this folding and internal movement the coal has itself been broken, compressed, twisted, and squeezed, as putty may be squeezed through the fingers, and in places there have been introduced into it large quantities of quartz and other rock impurities. Mining will be cheap in the pockets and expensive where the coal is thin, the net cost of mining probably running considerably higher than in the anthracite field of Pennsylvania. The possibility of using the associated clay rock for making paving brick, tile, and like products suggests itself, and such use may materially offset a part of the cost of mining in certain localities.

The apparent failures to mine the coal profitably appear to be due to four causes-first, improper preparation of the coal at the mines; second, attempted use in and with furnaces and with apparatus built for use of dissimilar coals; third, relatively low duty obtainable from the coal in comparison with competing coals per dollar of cost, and the special and particular handling required; and, fourth, stock jobbing. The attempt, for example, to burn Cranston coal in large sizes, fresh from the mine, in an ordinary furnace is doomed to disappointment. The attempt to pay dividends on a capitalization of several million dollars from the profits on a daily output of a few hundred tons of coal, improperly prepared and improperly used, can have but one end.

Rhode Island coal needs investigation rather than investment. Though it presents a field of peculiar interest to the practical coal operator who oommands sufficient funds, with the possibility of successful use on the spot in making power by modern methods with financial reward, its use as a basis of general stock selling is open to the gravest suspicion, and such stock should be avoided by nontechnical investors until the property represented has been examined for them by competent experts.

The attempt to sell Rhode Island coal in the open market under present conditions is almost certain to result in failure. The public at large has lost faith in this coal as compared with other coals used 


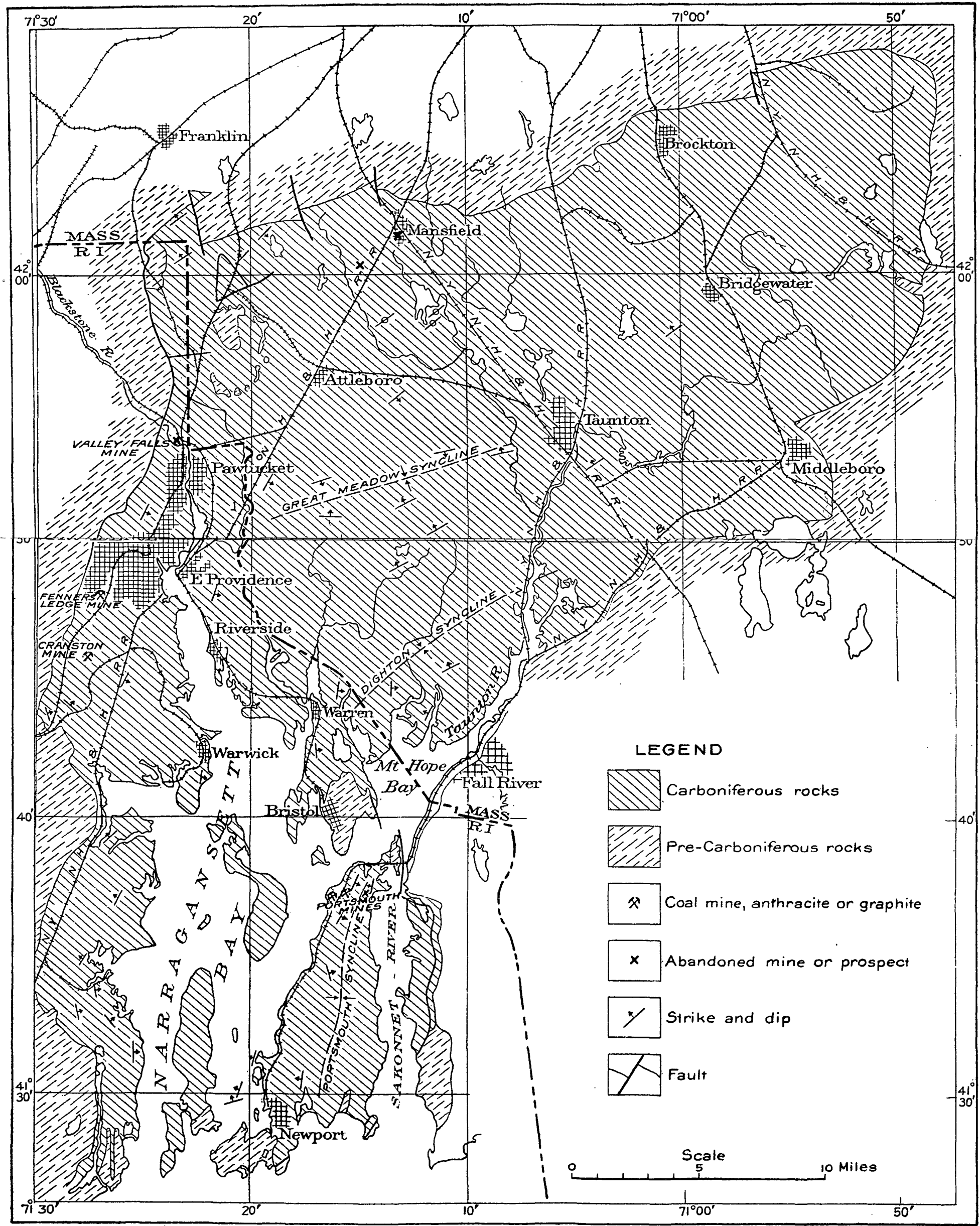

SKETCH MAP OF THE RHODE ISLAND COAL FIELD. 
in New England, partly because of its weight, making it appear small in bulk when delivered, partly because of the excessive amount of ash carried by most of it, but mainly because of the lower duty it usually renders when burned in the ordinary way. On the other hand, the sale of Rhode Island coal as electricity, ready for use by the turn of a switch, will avoid any possible prejudice or any failure because of improper use, and will avoid freight charges on the ash. Such use, therefore, possibly through the medium of the gas producer and gas engine, seems to be the proper aim of future successful exploitation. This use means a few plants specially built and specially manned. So utilized, it is believed that Rhode Island coal may afford a large field of profitable investment.

\section{HISTORY OF DEVELOPMENT AND USE OF RHODE ISTAND COAL. ${ }^{1}$}

\section{EARLY HISTORY.}

In studying the utilization of Rhode Island coal it is well to review the successes and failures of the past and then to learn, by experimental tests, possible methods of using not yet tried oommercially. - The "front" bed of coal at Portsmouth outcrops in plain sight in the low cliffs bordering Narragansett Bay on the west side of the island of Rhode Island, and beds of coal or carbonaceous shale have been encountered in digging wells in many places in Rhode Island and the adjoining part of Massachusetts, so that the presence of coal in the State has been known from a very early time. The coal at Portsmouth seems to have been known at least as early as 17.60. In February, 1768, patent was granted to parties who "were about to dig after pit coal or sea coal" in the hill at the back of the town of Providence, as shown by the acts and resolves of the Rhode Island General Assembly.

It is said that during the Revolutionary War the British soldiers in Newport used the coal from the island for heating. In an address in June, 1887, former Gov. Lippett said that his grandfather had attempted to mine Rhode Island coal more than a century beforethat is, prior to 1787 .

In 1808 the General Assembly of Rhode Island granted a lottery to raise $\$ 10,000$ in search of coal, and in that year two mines appear to have been opened on Butts Hill, in Portsmouth, one known first as the Aquidneck mine and later as the New England mine, and the other, on the east side of the hill, known as the Case mine. These mines were opened by Purton Nichols, who bought the land but was to give the old owner 1 bushel of coal for each 100 bushels mined.

1 This history has been culled from all available sources, especially the earlier geologic reports elsewhere referred to and the files of the Providence Journal. 
In 1809 the Rhode Island Coal Co. and the Aquidneck Coal Co. werè incorporated, and from $\$ 12,000$ to $\$ 15,000$ was then expended in exploiting the coal. In 1812 the general assembly granted a lottery of $\$ 40,000$ to the Rhode Island Coal Co., one of $\$ 30,000$ to the Aquidneck Coal Co., and one of $\$ 12,000$ "for the search for coal in Cumberland." Little money appears to have been raised by the granting of these lotteries, as Massachusetts refused to permit the sale of tickets in that State. According to a letter of Mr. Clowes (1828), these companies failed for want of practical skill and proper preparation of the coal, the effort being made to market it in large lumps. In the early history of the mines "round" coal is reported to have sold for $\$ 5$ a ton and slack for $\$ 2.50$. Prices were soon reduced to $\$ 3$ for round and 50 cents to $\$ 1$ for slack coal.

Coal was found in Cumberland in 1808 in digging a well near the house of Timothy Dexter, between Blackstone River and Abbotts Run, a little north of Pawtucket. Some drilling was done and a pit was sunk 80 feet to a bed said to have been 15 feet thick. Several hundred tons of coal were raised.

Some was given away, some was sold, and some used on the premises and in Providence and other towns. *** But few people knew how to use this anthracite. They would take it and place it on a common fire and, though it would burn in this way, yet it could not be so used to much advantage. Wood *** was then abundant, and there was no encouragement to working mines when other fuel was plentiful, *** so we did not consider it worth our while to continue the working of the beds. ${ }^{1}$

In 1828 interest revived and a new opening 60 feet deep was made to the coal. About 50 tons had been taken out when a fall of the roof killed the son of the proprietor and led to the abandonment of the mine.

In $1835 \mathrm{~J}$. Alexander and Seth Mason \& Bros. became interested at this locality and sunk a shaft to a depth of 40 feet, when, after a heavy rain, the shaft caved in. They then sunk a second slope to a depth of 45 or 50 feet, when their funds ran out and they found it necessary to incorporate; so in 1836 they incorporated as the New England Coal Mining Co. The slope was then continued down the coal bed to 78 feet, and machinery was set up. Drifts were then driven 300 feet on the coal and 600 tons of coal was raised, "the last of which sold readily for $\$ 6$ cash at the mine." The coal did not find favor, because, it is thought, it came from too near the outcrop and was not properly cleaned. About $\$ 1,500$ worth of coal was sold. About this time the surface buildings were burned.

In 1837 more money was raised by assessment and a 150-foot vertical shaft was started. At 60 feet the shaft was abandoned and, as a

\footnotetext{
${ }^{1}$ Hearing on the memorial of the New England Coal Mining Co. before the select special committee of the General Assembly of Rhode Island and Providence Plantations, together with the report of the committee, 1838 .
} 
last resort, the company, having expended about $\$ 20,000$, petitioned the legislature for financial aid. The mine was worked under a 25 -year lease, with a ground rental of $\$ 1,500$ a year and a royalty of 50 cents a ton. The memorial made to the legislature is filled with certificates as to the good quality of the coal, but the legislature made no appropriation.

After the failure of the two companies at Portsmouth others tried to work the mines without success. In 1827 it is reported that 2,200 tons were raised by 20 men and 5 boys, and sold at $\$ 4.50$ a ton.

Coal was known in Mansfield, Mass., in 1810. In 1835 three companies, advised and assisted by Dr. C. T. Jackson, were formed for mining the coal in Mansfield, namely, the Massachusetts Mining Co., at the Harden farm, 2 miles southwest of Mansfield; the Mansfield Mining Co.; and the Mansfield Coal Co. The Massachusetts Mining Co. expended somewhat less than $\$ 15,000$ and raised 1,200 to 1,500 tons of coal, worth from $\$ 5,000$ to $\$ 6,000$. All these mines had stopped work in 1838. One of the companies is said to have raised about 2,000 tons of coal. The mine on the Alfred Harden place is described by Jackson as 64 feet deep, with a gallery 40 feet long extending southeastward. Another, on the Otis Skinner place, half a mile to the northwest, was 85 feet deep and was equipped with a good engine. The third mine, on the Harris estate, was sunk to a depth of 100 feet and drifts were cut north-northwest and south-southeast. Jackson reports that the coal cost about $\$ 1$ a ton to extract, the mines raising 10 tons of coal on some days and hardly any on other days.

In 1840 it was estimated that about $\$ 40,000$ had been expended at Portsmouth.

Perpendicular shafts and horizontal galleries were excavated and a steam engine with an endless chain was used in getting out the water, the extra power being used to raise the coal.

\section{DEVELOPMENT FROM 1840 TO 1880.}

In 1840 the Rhode Island Coal Co. took over the Portsmouth property after some preliminary drilling had been done by a Mr. Spiker. Mr. Otis Peters was connected with this company. His mine was deepened from 100 to 400 or 500 feet. Three years later the property passed to a Hartford company, which, in turn, failed to make it successful.

In 1847 the Portsmouth Coal Co. reopened the old Case mine, on the east side of Butts Hill, but soon abandoned the enterprise. At that time the mine on the west side of the hill was being run by the Aquidneck Coal Co. In the last half of 1850 this mine yielded 3,100 tons of coal. 
In 1850 the Mount Hope Mining Co. took the old Case mine, giving it the name Mount Hope mine. Dr. Hartshorn, of Providence, and Gov. Jackson, of Rhode Island, were among the owners. About the same time a mine was opened in Bristol. The Aquidneck Coal Co., working on the west side of the hill, deepened their mine from 150 feet down the slope to 625 feet. In 1852 they were employing 55 men and raising 75 to 100 tons a day, using two 40 -horsepower steam engines for pumping, hoisting, screening, and assorting the coal for market. The cost of mining was then estimated to be $\$ 1$ a ton.

This company tried hard to induce the use of the coal by large manufacturing plants, going so far as to send a man, John Corrigan, to manufacturers to show them how to use it. For a time, apparently, a considerable trade was built up, but it was found that when the coal was used by the regular firemen the furnace walls were melted, and, as a whole, the great care required in its use was too much of a burden, so people refused to use it. The company lasted three years, and the mines were then taken over by a Worcester company, which ran for a few years and sold out to the Taunton Copper Co.

The Taunton Copper Co. is the one shining example of continued successful use of Rhode Island coal. This company opened the North mine before 1860 and continued operating until 1883, building a dock and railroad connections. Though most of the coal used came from the North mine, the South mine was extended from 700 or 800 feet to 1,600 feet. A copper smelter was built and coppe 'ore was brought in from Cuba and South America and smelted. 'T'his company, of which Mr. S. L. Crocker, of Taunton, was president, mined about 10,000 tons of coal a year. The coal was also used to some extent for domestic purposes and at least "several cargoes" were shipped to Poughkeepsie, where they were used successfully in the furnaces of the Poughkeepsie Iron Co. The imposition of a high protective tariff on copper ores and the death of the principal owner of the plant resulted in its closing.

Meanwhile, the Pocasset Coal Co. had opened up the Cranston coal. In 1866 Heald, Britton \& Ford, of Worcester, wrote that they had used some of the Cranston coal; that they were satisfied with it and thought it improved the strength of the iron. In 1868 the agent for the Pocasset Coal \& Iron Co. stated that during his agency 3,600 tons of coal had been mined and teamed from Cranston to Providence. ${ }^{1}$ In order to introduce it, it was sold under the price of Pennsylvania coal and is said to have been used largely by the Mount Hope Iron Works, G. G. Hicks Boiler Works, and other establishments.

In 1874 a careful test of Cranston coal was made at the Sockanosset pumping station of the Providence Waterworks. (See pp. 42-43.)

\footnotetext{
${ }_{1}^{1}$ Memorial of T.S. Ridgway in relation to the coal field of Rhode Island, presented to the General Assembly, 1870. 
The test does not seem to have led to the use of Cranston coal by the city and apparently mining was abandoned except in a very small way. A Mr. Moore at this time used the product of a small mine in his facing works at Elmwood.

During this period both the Valley Falls mine and the Roger Williams mine, a mile to the north, were in operation part of the time. In 1853, according to Mr. E. T. Hitchcock, the Roger Williams mine, which had been worked at an earlier date, had been recently reopened by a 300 -foot vertical shaft. From this a drift 260 feet long had been run, striking a bed from 15 to 25 feet thick. It was thought by Mr. Hitchcock that this bed was probably a pocket, and the fact that it was not worked very long sustained that impression.

The Valley Falls mine was at that time being worked by the Blackstone Coal Co. The mine consisted of an incline 500 feet long, reaching to a depth of 375 feet and working on a coal bed 6 to 8 feet thick. It is said that four other beds were found at that point. Hitchcock said that the coal burned well, though in its most recent history the Valley Falls mine is reported to have mined chiefly material for furnace linings.

\section{RECENT HISTORY.}

In 1885 the New York Carbon Iron Co., of Pittsburgh, became interested in Cranston coal. They were then using a patent process, invented by Dr. C. J. Eames, for making billets for blooms. In 1886 their metallurgist, Richard Eames, was sent to Cranston to supervise the opening of a mine and the shipment of coal. He found that the mine on the Harris place consisted of an open cut with a slope 225 feet long and 40 feet deep. He opened a shaft 75 feet deep and equipped it with buckets capable of raising 30 tons a day. From the bottom of the shaft five chambers were opened, four of them being 40 feet square and the fifth 95 feet long, 15 feet wide, and 20 feet high. They employed 30 men, and for a time in 1887 shipped to Pittsburgh 250 to 300 tons of coal a week. This was certainly "shipping coals to Newcastle," but the company seems to have found its use successful and economical. No record was found showing how long this use of the coal continued, but apparently it did not last long.

In 1887 W. F. Durfee, of New York, became interested in the establishment of a blast furnace at Portsmouth for working the Cumberland iron ore. For a time he stirred up considerable public interest. In an address before the board of trade, June 7, 1887, Mr. Durfee quoted Prof. R. H. Thurston as approving the use of Rhode Island coal in the smelting of copper ore and in modern high smelting furnaces. He cited the successful use at Pittsburgh, and in the past at Poughkeepsie, quoted favorable extracts from letters from other users, and suggested its possible future use in the manufacture of fuel (water) 
gas. Possibly as a result of this agitation, in 1889 the Worcester Steel Works, of Worcester, Mass., reopened the three mines at Portsmouth, which had been idle since 1883 and which had filled with water. This included not only the South and the North, or Crocker, mines, but also the Mitchell mine on the west side of Butts Hill, which had been opened by Thomas Mitchell in 1871-72 and sunk to a depth of 80 feet. At the same time Miles Standish, of New York, leased the Hazard or Case mine and adjoining property. In May, 1889, 70 miners were employed, though the mine was still being pumped out. At that time the company expected to employ 300 men as soon as the mine had been completely unwatered. It was also the intention to erect a blast furnace and foundry at Portsmouth and mine Cumberland iron ore. The project was not successful and the property reverted to the Rice heirs, of Boston, and remained idle for 20 years, or until 1909.

Meanwhile, attempts were made to mine the coal at Cranston, usually by stock companies. It is reported that not less than seven companies were so formed during recent years. These companies may be typified by the Cranston Coal Co., which was active two or three ycars ago. This company was organized with a capital of 1,000,000 shares, having a par value of $\$ 5$, and the coal was offered at $\$ 5$ a ton, as against $\$ 6.50$ to $\$ 7.50$ for Pennsylvania anthracite. Halftone photographs in their advertisements show work being carried on in an open cut, which has much the same appearance as the cut has to-day. A rough estimate indicates that in all of the years this mine has been opened not more than 10,000 to 15,000 tons could havo been removed, so apparently a very small amount of coal could have been mined and sold by this company.

When visited by the writer in October, 1913, the Cranston mines consisted still of an open cut about 300 feet long and a slope, then full of water, less than 100 feet long, from which rooms had been turned off. A dozen men were getting out about 60 tons of coal, which was being hand screened after crushing into small sizes for domestic use by Mr. Budlong and families in neighboring houses. The coal was being mined by drilling and blasting, as rubble is quarried; it was then loaded into buckets and placed on cars, which were pushed by hand a short distance, then raised from the cut by a derrick. The coal next went to a crusher and was then screened. When the mine was visited the coal was being rescreened by hand and bagged. Plate II, $A$, shows the open cut and Plate II, $B$, a closer view of part of the face of the coal at Budlong mine, Cranston, R. I.; Plate III, $A$, shows the surface plant; and Plate V, $A$ (p.19), shows the north end of the mine accompanied by a diagram, Plate $\mathrm{V}, B$, that indicates the coal and its variations in thickness within a few feet.? 


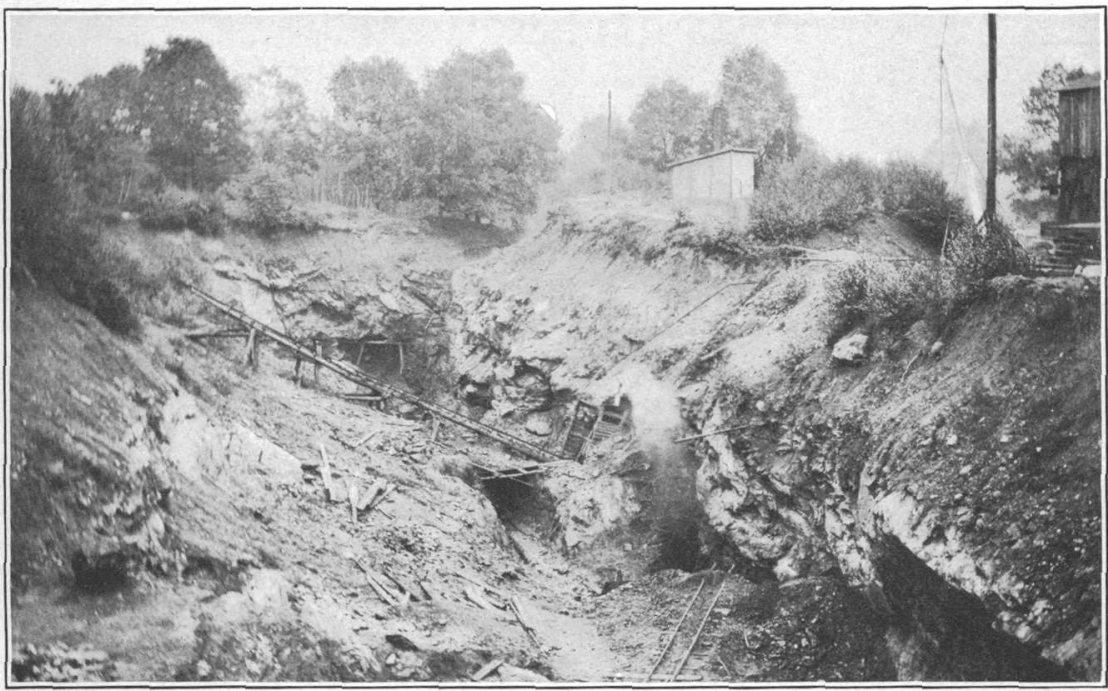

A. OPEN CUT IN MINE, LOOKING NORTH.

Mouth of slope with part of incline tra $k$ in center. Blast going off just to the right. Dip of bed is shown by base of overlying rock in lower right corner.

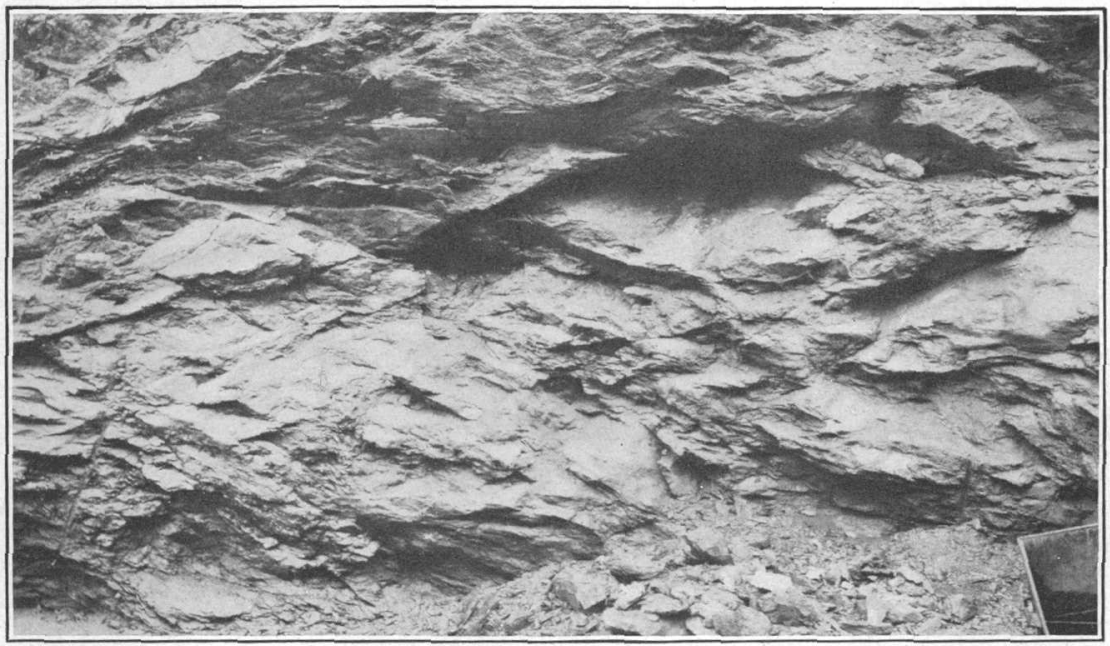

B. FACE OF BED A LITTLE NORTH OF THE MOUTH OF THE SLOPE, SHOWING THE CHARACTERISTIC SCHISTOSE OR SQUEEZED-LENS APPEARANCE OF THE COAL.

VIEWS AT BUDLONG MINE, CRANSTON, R. I. 


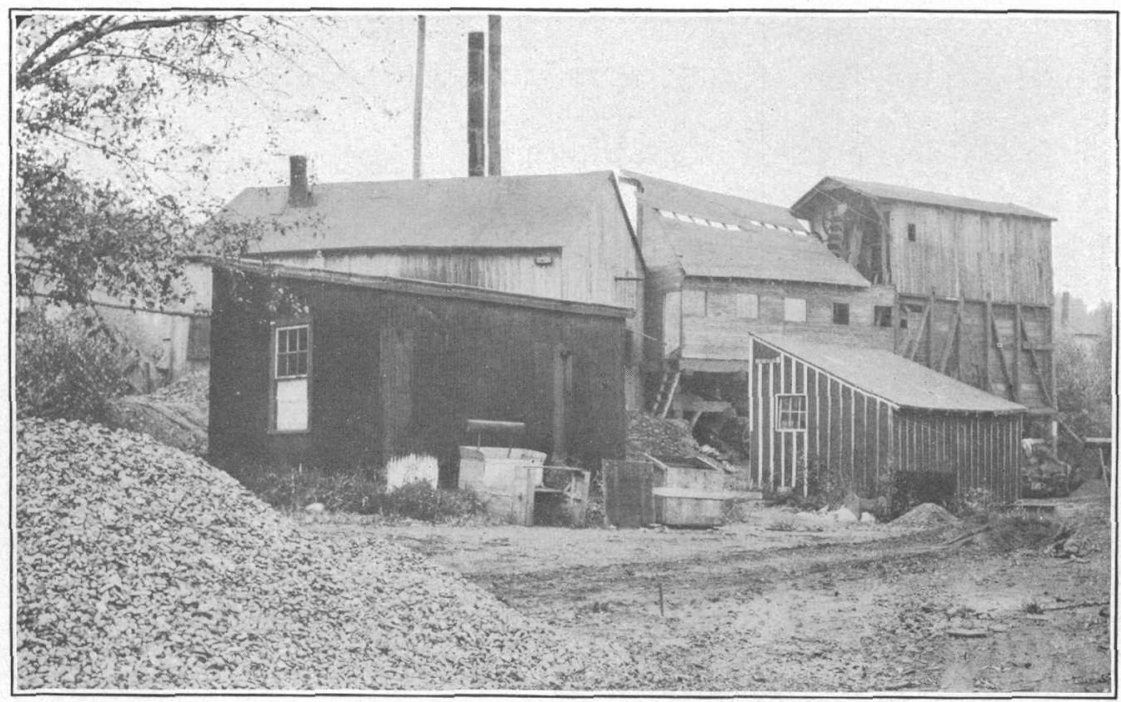

(1)

A. SURFACE PLANT AT BUDLONG MINE, CRANSTON, R. I.

A pile of hand-screened coal is seen in the foreground.

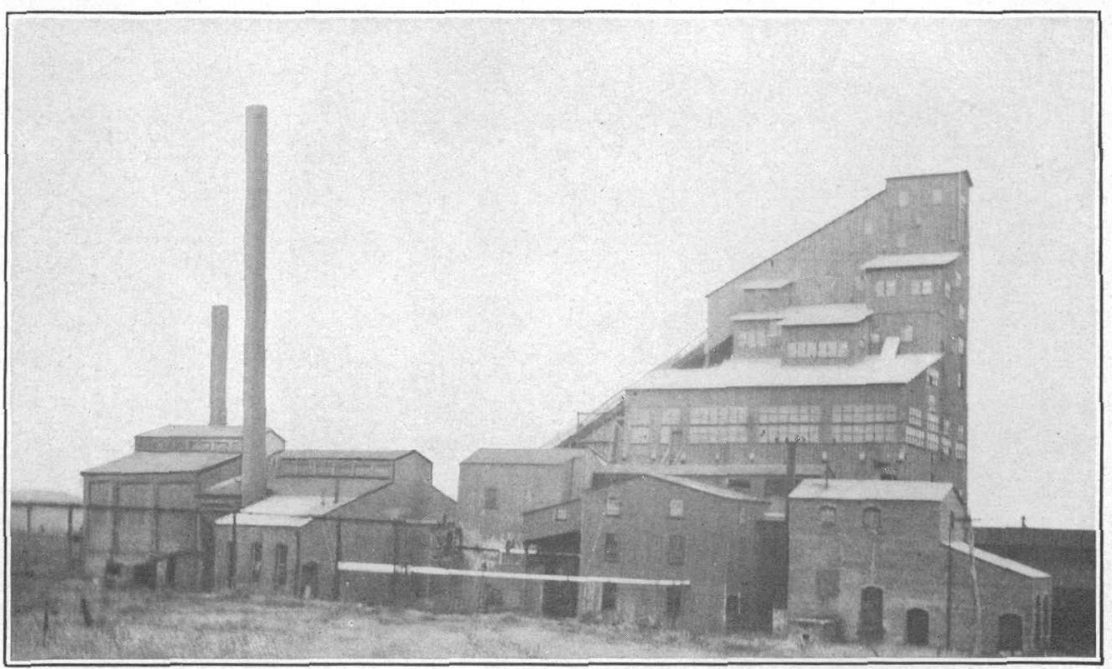

B. SURFACE PLANT AT SOUTH MINE OF PORTSMOUTH COAL CO., PORTSMOUTH, R, I. 
In 1898 Boston parties, under the title "Compressed Coal Co.," took hold of the Portsmouth mine and put in a briquetting plant. The plant, part of which had been moved from Arkansas, made egg briquets, using the Zwoyer process. Most of the material briquetted was taken from the old culm pile at the North mine and consequently was high in ash. The briquets did not find a ready market, the attempt appears to have shared the common fate, and the mines were again allowed to fill with water.

While this small development was going on at Cranston a new and much larger development was taking place at Portsmouth. Somctime previous to $1909 \mathrm{Mr}$. J. W. Dennis became interested in a process of briquetting that was patented by N. W. Bloss, by which Chile saltpeter is used to aid in the burning of the coal. Dennis experimented with this process and afterward with a process patented by H. J. Williams, of Boston. In the Williams process crude calcium chloride is used, as it cost only $1 \frac{1}{2}$ cents a ton for the treatment, as against 12 cents for the saltpeter. The coal was treated by immersion in a solution of calcium chloride. It was contended by $\mathrm{Mr}$. Williams that, whereas the raw coal kindled with difficulty and gave a flame only 5 to 8 inches long, which soon disappeared, the treatcd coal gave a flame 36 inches long for an hour and a half, after which it gradually decreased but remained long for' several hours; that it kindled more rapidly and gave a hotter fire. It is said that after three years of practical tests and demonstration the method was submitted to H. M. Whitney, resulting in the formation, in February, 1909, of the Rhode Island Coal Co., with a capitalization of $\$ 5,000,000$, the company being incorporated in Maine. The company purchased 400 acres and obtained control of the coal rights of 4,000 additional acres. During the spring and summer of 1909 the mine was pumped out, the slope entrance was enlarged and straightened, and the mine was cleaned up. Ultimately the South mine was equipped with a breaker, air compressors, large hoisting engines, a briquetting machine, and other appliances. (See Pl. III, B.) The coal dust was briquetted by the R.A.Zwoyer process, Mr. Zwoyer being employed as the briquetting engineer. The slope was extended to 2,100 feet, on the same average dip of $31^{\circ}$, to the bottom, though the dip became steeper toward the bottom rather than flatter. Pumps were put in, the walls at the mouth of the mine were cemented up, and the whole mine apparently was put in good condition for work. Additional core drilling was done and the success and future of the new enterprise was told in glowing terms in full-page descriptions in the daily papers. Estimates were made that the output would be 4,000 to 5,000 tons a day, at a net profit of $\$ 2.50$ to $\$ 3$ a ton. This would have yielded from $\$ 200,000$ to $\$ 300,000$ net profit each month. By December, 1911, the gross receipts are reported to have reached 
$\$ 12,175$ for the month. In February, 1912, the company went into the hands of a receiver. At the time the mine was visited by delegates of the Providence.Association of Mechanical Engineers, May 20, 1911 , there were reported to be 82 miners employed, earning from $\$ 6$ to $\$ 7$ per week, at the rate of $\$ 1.50$ a car. The mine was then using 14 mules underground. Later the company was reorganized as the Portsmouth Coal Co. On December 31, 1912, the published report of the company's finances showed accounts and notes payable exceeding the cash and other assets by more than $\$ 75,000$, and in January, 1913, after the receipt of the experts' report, the directors of the company advised the stockholders that the mine had been abandoned. The pumps were kept going until July, 1913, but when visited in October the mine had filled up to the 1,400-foot level and the water was gradually submerging the pumps and other machinery.

\section{DEVELOPMENT'IN 1913.}

In October, 1913, the conditions in Rhode Island with reference to mining may be briefly summed up as follows:

Three mines were open, two of which were running. At the Fenner Ledge, near Providence, 3 men, working under Mr. Fenner, were getting out about 3 cars of graphite a month, which was selling at more than $\$ 7$ a ton. At the Cranston mine, on the Harris place, near the Sockanosset Reservoir and the Reform School, about a dozen men were getting out a few tons of coal from an open cut for household use. This coal was being hand-screened and bagged. Bituminous coal was being used under the boilers at the mine. The slope was full of water. At Mr. Budlong's nursery a considerable quantity of small coal was stored in the open for use during the summer, when the duty required of the engines was smaller. During the winter soft coal was used exclusively. At Portsmouth both mines were equipped for raising coal. The South mine was also equipped with briquetting machinery, air compressors, and other appliances. The mines were well supplied with pumps, mine telephones, and other equipment, but were gradually filling with water. The graphite mine near Central Falls had not been active for several years and was fallen shut. The graphite deposit near Tiverton was not visited and its condition is not known. In January, 1914, it was reported to the writer that the mines at Portsmouth were being dismantled.

\section{CONDITIONS AFFECTING METHOD AND COST OF MINING.}

As already stated, the coal beds and the associated rocks have been subjected to intense horizontal pressure, so that not only has the internal structure of the coal been affected, but the coal beds 
and other rocks have been compressed into great folds. Unfortunately for mining, the folding is in many places very complicated. The coal, which is relatively soft, has yielded more than the surrounding rocks, so that the beds have lost their original regularity and now occur in pockets, irregular in size and shape, separated by more or less extensive areas of thin coal or areas from which the coal has been entirely squeezed out. Furthermore, the varying intensity of the pressure from place to place has also resulted in considerable differences in the quality of the coal; in some areas it has been converted entirely to graphite with a large admixture of ash; in others, where the pressure was less, the percentages of graphite and ash are much less or very low.

In view of these conditions it must be recognized that Rhode Island coal can not be nined on a large scale according to a regular plan, as most coal may be. Such mining, like most metal mining, will face uncertainties as to the position, the quantity, and the quality of the mineral sought. These uncertainties will probably be greater in some parts of the field than in others. In flat-lying regular beds of coal 5 to 8 feet thick practically all the digging is in coal and all the product may be sold. The mine may be laid out in regular entries at regular distances apart, from which rooms of equal length are turned off at regular intervals and the intervening pillars so mined out that, ideally, no coal is left in the mine. Furthermore, haulage is a simple matter, as the motors may be taken into the rooms or shifted to any part of the mine without difficulty.

By contrast, in the Rhode Island coal field extensive prospecting will be necessary to determine the location of the lenses of workable coal. The mine must be developed along the irregular lines determined by the lenses, and a considerable portion of the digging will be in rock, as where the coal is thin, or where it may be necessary to diverge from the bed in order to keep the haulage ways on fairly even grade. This rock digging costs as much as or more thian the digging in the coal and does not yield a salable product. As the shape and position of the leinses of thicker coal can not be known until the coal is mined out, it will not be possible to plan entries and rooms so as to remove the coal at the least possible cost.

To these special costs, due to the irregularity of the beds, must be added the usual higher cost of mining by slope or shaft as compared with drift mining and the higher cost of mining and haulage in highly pitching beds as compared with flat-lying beds. These and many other elements of cost may not differ greatly from similar costs in the anthracite fields of Pennsylvania or in small areas in other fields of the United States, provided that the coal at any place maintains a fairly uniform dip, as it does at Portsmouth, and fairly uniform thickness, which will probably not be found in any part of 
this field. If, however, the coal bed is crumpled into S-shaped curves, or other curves of fantastic shape, as the surface indications in some areas suggest, the cost of removing the coal may be greatly increased.

The cheapest coal bed to mine has a thickness of 6 to 8 feet. Where the beds run under 6 feet, the cost begins to rise, at first slowly, but more and more rapidly as the thickness decreases. For equal areas, a 3 -foot bed yields only half the tonnage of a 6 -foot bed, but involves for the same tonnage of yield the care of double the amount of roof and the laying of double trackage, besides the additional cost of supervision and many other items. The mining rate usually begins to increase rapidly as the thickness of the coal goes below 3 feet, and as the decrease continues the proportion of rock that must be mined and paid for without return steadily increases, so that for beds from 1 foot to 18 inches in thickness the cost per ton may be two or three times the cost of a bed from 3 to 6 feet thick. On the other hand, experience has shown that under usual conditions the cost of mining per unit of output does not continue to decrease as the bed increases in thickness beyond the zone of minimum cost, for what is saved in trackage and other items is more than made up in the increased cost of timbering or decrease in percentage of recovery.

If the shale or clay lying next to the bed of coal can be used commercially it may be mined with the coal and thus the cost per ton for mining the coal may be greatly reduced. In studying this field, therefore, attention should be given to the character of the shale or clay adjoining the coal. The writer would suggest that the shale accompanying the coal at Portsmouth be tested for use in the manufacture of paving brick and draintile.

Another element to be considered is the uncertainty of the extent of the beds or of their persistence in character. This field has not yet been sufficiently explored to show whether the beds are extensive or whether they were originally laid down in small basins. As this matter is being studied by the State survey, under Mr. Brown, the writer did not make a detailed examination of the coal beds, such as would be necessary to discriminate between differences of thickness due to pressure from those due to the differences of original deposition of the bed. The mining at Portsmouth strengthens the belief that the beds there may at first have been very regular, though mining and prospecting have not yet been extensive enough to indicate whether the Portsmouth area is more than a local basin. On the other hand, a comparison of the sections at the Sockanosset mine with those at Fenners Ledge suggests variability in quality if not in extent. 
In view of the conditions mentioned, it is evident that mining on an extensive scale in Rhode Island should not be undertaken until the field to be mined has been thoroughly and completely tested by the diamond or core drill. A hole should be drilled in each 10 acres or smaller area and the coal cores analyzed. The fact that once or twice extensive drilling of this kind has been carried on in this field and was not followed by an attempt at development indicates that the results were not all that might have been hoped for. Thus the Portsmouth field was drilled across by Mr. A. B. Emmons in 1883-84, but the results did not lead to development.

At present the only mine that might furnish data as to cost is that at Portsmouth. The coal at Sockanosset has been mined either in open cut by ordinary quarry methods or by shallow slopes, neither of which can afford data for computing the cost of mining on a large scale under existing conditions. Evidence from several sources indicates that the cost will average not less than $\$ 2.50$ a ton, a figure given by Shaler in discussing the subject in 1899 and quoted by the superintendent of recent mining operations at Portsmouth. As the cost of mining coal tends to increase as the mine workings increase in extent, the actual cost of extensive mining will probably exceed $\$ 2.50$ unless it is possible to utilize the shale that lies next to the coal.

\section{CHaracter OF THE COAL.}

\section{GENERAL FEATURES.}

Physically and chemically the coal varies greatly from place to place, both in the field as a whole and within any one mine. Coal is an indefinite mixture of carbon, hydrogen, oxygen, nitrogen, and sulphur, and of other materials which do not burn and which are grouped together as ash. Carbon is the principal element. In part it appears to occur as uncombined carbon, or, as it is commonly called, "fixed carbon," and in part it is combined with hydrogen and possibly oxygen in different combinations. The oxygen is so combined with hydrogen that in the combustion of the coal the oxygen and oneeighth of its weight of hydrogen, if so much is present, passes off as moisture without adding to the heating value of the coal. Small quantities of nitrogen, sulphur, and other substances are usually found in the coal, besides the ash, which is mainly material that has been added to the original vegetable matter and which may range from 1 or 2 per cent to 50 per cent or more.

\section{FIELD CONDITIONS.}

Coal has been derived from vegetable matter which, when buried in quantity in the earth and subjected to pressure and heat, undergoes changes and gradually loses part of the hydrogen combined with $97887^{\circ}-$ Bull. $615-15-2$ 
carbon, so that there is a consequent proportional increase in the percentage of uncombined carbon. In the lower grades of bituminous coal the uncombined or fixed carbon ranges from 40 to 55 per cent of the coal. Where the coal has been subjected to greater pressure or heat, the fixed carbon may increase to 65 or even to 75 per cent as in semibituminous coals. Where the coal has been subjected not only to the pressure of the overlying rocks but has been strongly compressed from the side, so that the beds are folded into great folds, as in the anthracite field of Pennsylvania, the fixed carbon may form 80 or 90 per cent or more of the coal.

In the Rhode Island field the pressure on the sides appears to have been still more intense, not only folding the rocks in great folds but crushing, squeezing, and shearing them with accompanying heat so high that in some places they have been changed chemically and physically. As a result of this intense pressure and heat the coal of Rhode Island has been changed to anthracite containing a high percentage of fixed carbon, and in places the material of the beds has flowed, like so much putty squeezed in the hand, until the original structure is practically all lost and all or nearly all traces of the combined carbon and hydrogen have been driven off, so that there the material has reached the last stage and become graphite.

In many regions of intense pressure and folding though the harder beds of rock may maintain their thickness and character with little change, any softer rocks, such as clays or coal, tend to yield, flowing away from the points of greatest pressure and accumulating in areas of less pressure. In these areas the intensity of pressure varies with some degree of regularity, appearing to be greatest at intervals or nodes along certain lines and least in other lines, somewhat after the manner of waves of water or air. The position of these lines with their nodes in any area must be worked out in the field, as the causes of this variation are not yet well understood.

In the Rhode Island coal field the coal beds are associated with clay rocks that have yielded with the coal beds, though apparently not to the same extent. This has allowed a greater variation in the position of the coal beds than would otherwise have occurred. As a result, the coal instead of forming a string of regular lenses connected by areas of thin coal may in places occur in lenses that are extremely irregular. Plates IV and V show in outline the type of lenses being mined at two points near Cranston.

An examination of the coal at different points in one of these lenses shows a considerable difference in the character of the coal. Wherever there has been a plane or surface in the coal along which considerable sliding has taken place, the coal in that surface appears to have been more heated and metamorphosed than the rest, and has 


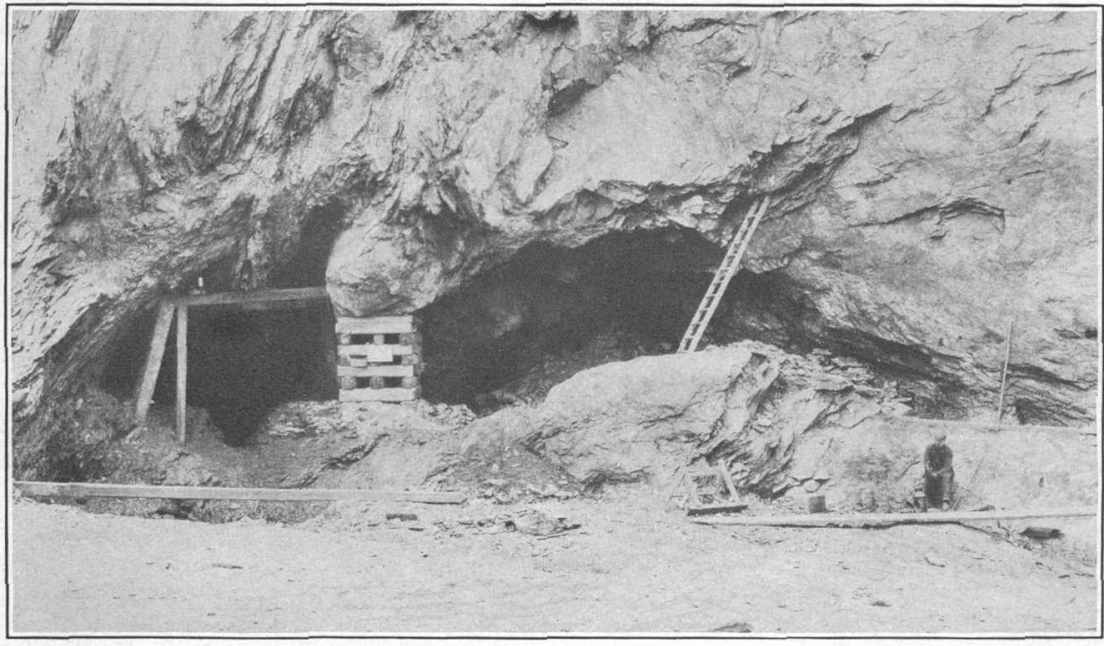

A. VIEW IN GRAPHITE MINE AT FENNERS LEDGE, NEAR PROVIDENCE, R. I.

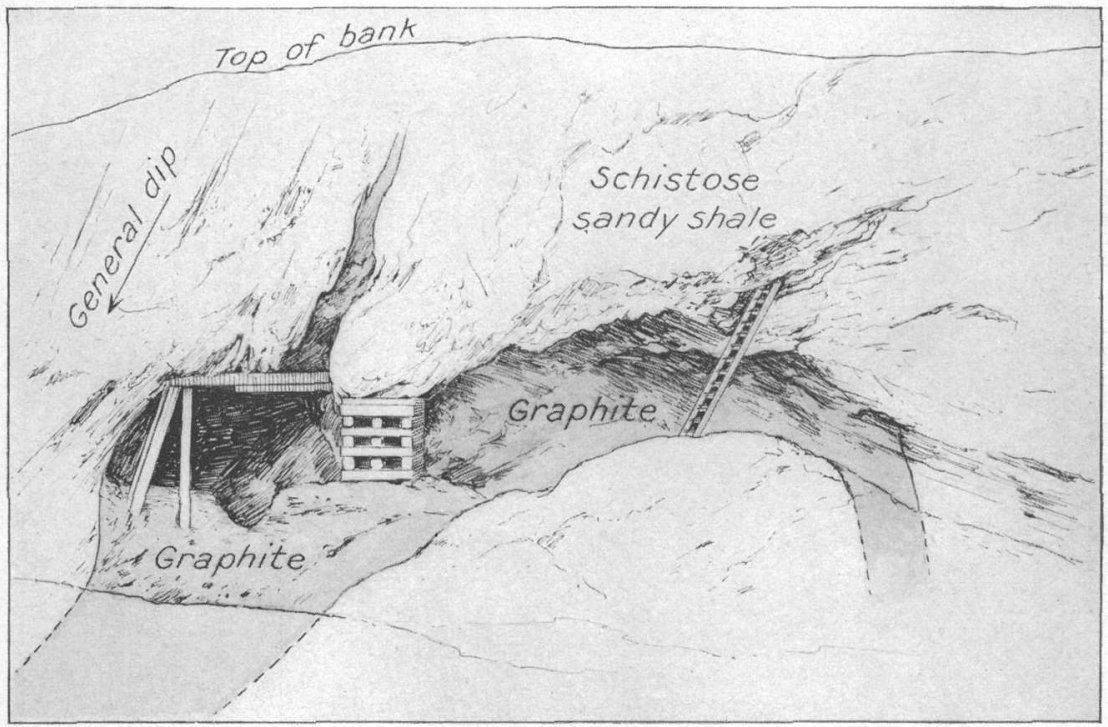

B. DIAGRAM SHOWING DISTORTION OF THE BED REPRESENTED IN $A$.

The bed nearly pinches out above the present workings. The best graphite being mined was found at the right, in a sort of tongue squeezed out in the folding of the rocks. 


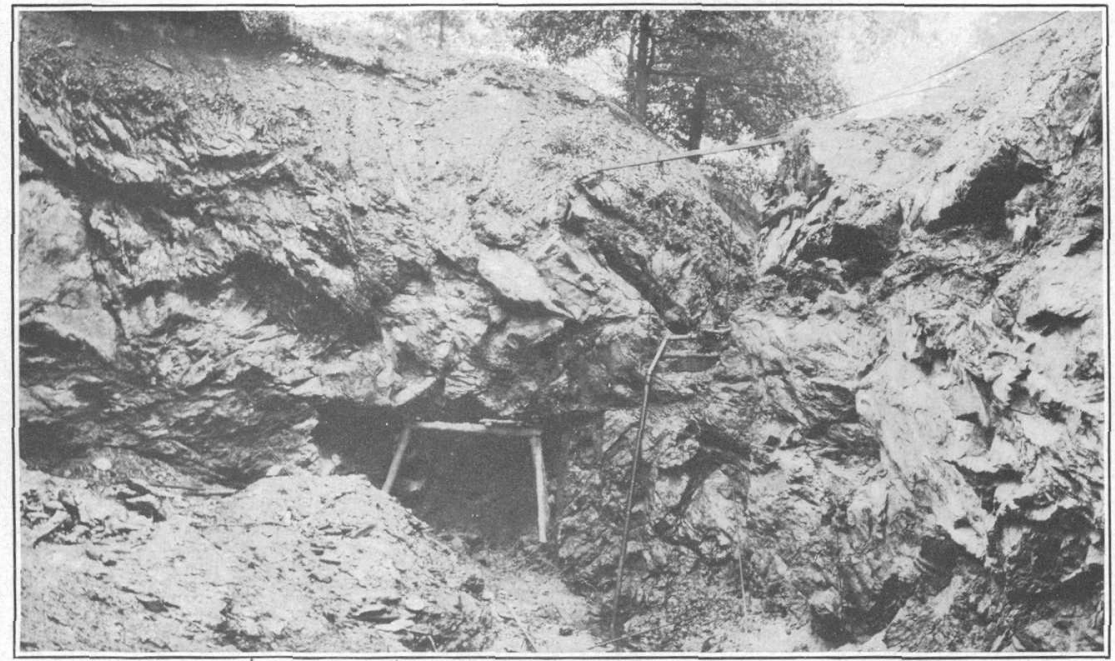

A. VIEW AT NORTH END OF BUDLONG PIT, CRANSTON, R. I.

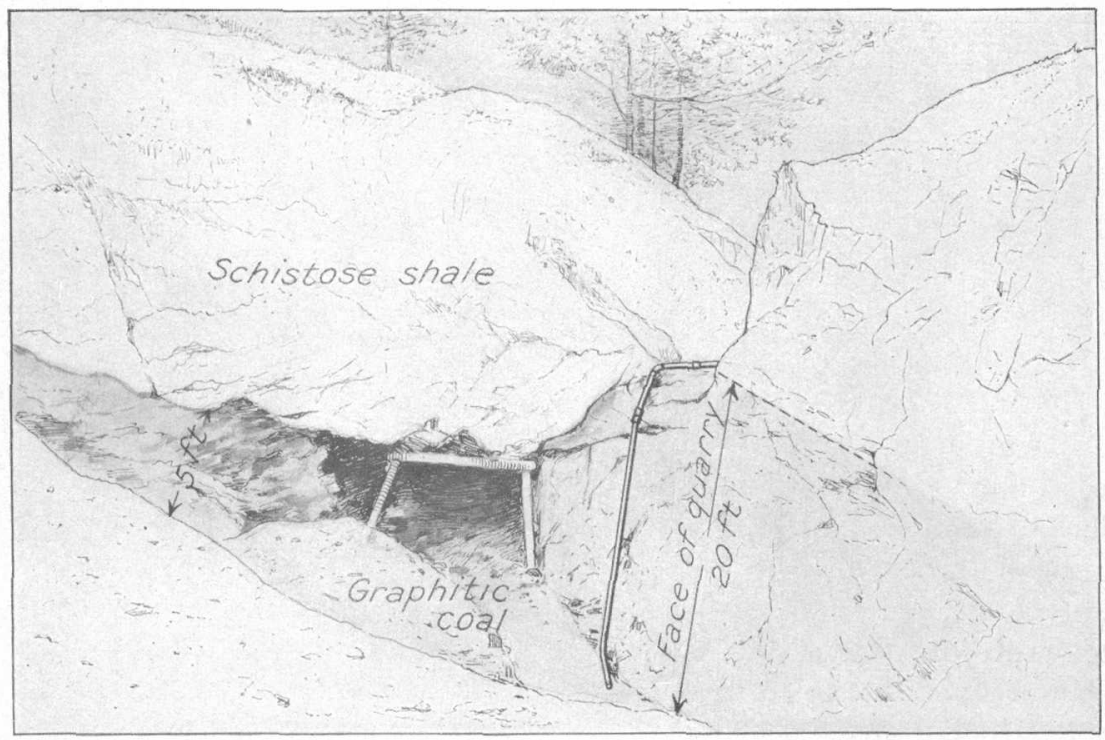

B. DIAGRAM TO SHOW VARIATIONS IN THICKNESS OF ANTHRACITE AT NORTH END OF BUDLONG PIT, SHOWN IN $A$. 
become graphitic. In places the whole bed has been squeezed until it was forced to flow to areas where the pressure was less, and to such an extent that all the coal appears to be graphitic. In general, the thinner the coal is at any point the larger the percentage of graphite it contains, as though internal movement had been greater at those points.

It is clear that this oompression and movement in the coal has been slow, at times breaking the coal so as to leave open crevices and then compressing and recementing it. In places where such open crevices have been formed temporarily water containing quartz in solution has flowed into the crevices and the quartz has been deposited in some places as a network through the coal. Where the beds are much metamorphosed, as at Fenners Ledge, a considerable quantity of asbestos is associated with the carbonaceous material. The crushed structure of the coal is shown in figure 1. The structure is well brought out by the minute lenses of quartz and pyrite.

The breaking open and recementing of the coal appears to have permitted the injection into it of more or less of the adjoining shale rock, so that, in general, where the coal is thin from having been squeezed out it is much higher in ash than elsewhere, the high ash appearing to increase with the increase of graphite. The ooal in the same mine may

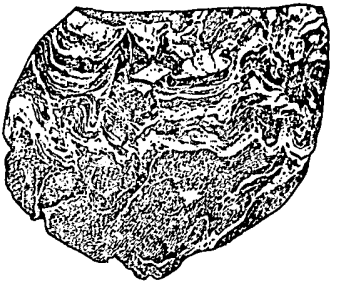

FIgURE 1.-Crushed structure of coal. therefore vary greatly from place to place, being high in graphite and ash in places where as a rule it is thin, and being freer of both ash and graphite in the pockets.

The field as a whole appears to have been subjected to large regional differences in pressure and there are corresponding regional differences in the character of the coal. For example, a comparison of the ooal at the Portsmouth mine, which is toward the middle of the basin, with the coal and other rocks at places along the edge of the basin suggests that in general the coal beds and aocompanying clay rocks have undergone greater distortion and change at the edges of the basin than at points in the center. The pressure in the oenter of the basin appears to have been relieved to some extent by the yielding and crushing of the rocks on the edge of the basin, where they were compressed against the older, harder rocks.

Unfortunately the coals in most of the interior part of the basin appear to be buried too deep for mining. Future prospecting may reveal increased areas of coal on the arches of anticlines, or in blocks brought up by faulting, that will be within mining distance of the surface and yet have the advantage of being less disturbed and changed than the beds now known around the edges of the basin. 


\section{PHYSICAL APPEARANCE.}

The best coal seen approaches Pennsylvania anthracite in color, fracture, and luster. The fracture, however, is less conchoidal and the color invariably tends to be more of a steel gray, none of the coals seen showing the bright jetlike luster of freshly broken Pennsylvania anthracite. But little difference was noted in the color of the best coal from Portsmouth and the best from Cranston, though the average coal at Portsmouth differs considerably from that at Cranston. In fracture the best coal at Portsmouth tends to break down in rhombs with short, irregular faces instead of with the rounded conchoidal surfaces of broken anthracite. In some specimens the rhombs are closely diamond-shaped in cross section with parallel faces. Other specimens of the coal appear to consist of a series of irregular plates, as though it had been cleaved by transverse pressure and the plates then pushed over each other but finally cemented together into a coherent mass. In still other specimens the coal appears to have been broken into minute fragments of all shapes, which were later recemented and consolidated like a conglomerate or breccia. The color of such pieces ranges from steel gray, locally slightly bronzed, to a dull black, like the oolor of manganese. Much of this coal, in fact, is dull bluish gray to black, with bright luster in spots, grading into black without luster. Though hard, this coal as a rule is friable and requires careful handling in shipping to prevent slacking.

In the Cranston district the coal everywhere seen differs both in appearance and fracture from the Portsmouth coal, the olosest resemblance noted, both in oolor and fracture, being in coal said to have come from the foot of the incline at the Budlong mine. As a rule the Portsmouth coal appears to have been broken into minute fragments by a close network of fracture planes, but the coal at Cranston has more of a flow structure, the original rhombic fragments, if there were such fragments, having been pressed and drawn into scales or flakes. Pieces of the coal, large or small, everywhere present smooth, rounded surfaces, rubbed and polished or glistening. These surfaces appear in many specimens to consist of at least a film of graphite. Exceptionally, the entire piece appears to be composed of thin scales or flakes of graphite, held together more or less imperfectly. Such pieces will make a mark as readily as a pencil, and have an oily feeling when rubbed with the fingers. Much of the gray appearance appears to be due to films of a grayish or bluishwhite substance, apparently quartz that has been carried into the coal in solution in water; and the same solutions also carried in more or less pyrite or iron sulphide, the "sulphur" of the miners. In places the quartz forms veins or irregular plates an inch or two thick, commonly with a lens of pyrite running through the center. 
The best of the Cranston coal shows almost no quartz or only in minute scattered flakes or films. The poorer coal looks as if it had been dipped into some gray solution and then dried. The poorest coal is full of distinctly visible quartz veins of considerable thickness and extent and, where mined near the surface, is commonly stained rusty red from the oxidation of the pyrite. In fact, much of the coal at Cranston, if picked up beside the road, would not seem to be coal nor to have any of the qualities of a fuel. It shows a bluish-gray to ashen-gray color, changing in places to a dull or glistening black, and has the structure of a foliated schist. Much of this coal would be defined by a geologist as a carbonaceous schist.

\section{SPECIFIC GRAVITY.}

The weight or specific gravity of Rhode Island coal has operated against its use. Pennsylvania anthracite, as delivered, has a volume of 35 to 40 cubic feet per short ton, according as the coal is broken large or small. Much of the Rhode Island anthracite in the same sizes has a volume of only 25 to 30 cubic feet per ton. The householder who has been accustomed to the ordinary-sized load of Pennsylvania anthracite is inclined to think when he receives a load of Rhode Island anthracite that he is getting short measure or to believe that the smaller volume of the Rhode Island coal can not give as much heat as the larger volume of the Pennsylvania coal. He thus at once becomes prejudiced against the coal or the use of it.

The writer had the specific gravity determined of five samples of Rhode Island anthracite and one of Pennsylvania anthracite in the chemical laboratory of the United States Geological Survey. In order to learn to what extent ash affected the specific gravity, C. E. Lesher later determined the ash from the same samples. The results obtained are as follows:

Specific gravity and ash of Rhode Island coal.

\begin{tabular}{|c|c|c|c|c|}
\hline No. & Sample. & $\begin{array}{c}\text { Specific } \\
\text { gravity. } a\end{array}$ & Ash.b & $\begin{array}{l}\text { Air-dry- } \\
\text { ing loss } \\
\text { at } 60^{\circ} \mathrm{C} . b\end{array}$ \\
\hline $\begin{array}{l}1 \\
2 \\
3 \\
4 \\
5\end{array}$ & 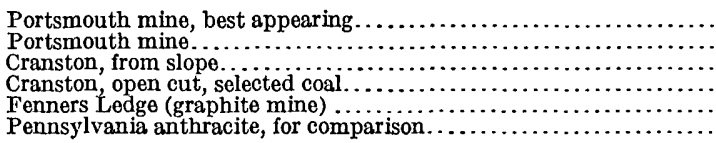 & \begin{tabular}{l|}
1.65 \\
1.96 \\
2.20 \\
2.06 \\
2.45 \\
1.43
\end{tabular} & $\begin{array}{r}13 \\
.13 \\
18 \\
6 \\
65 \\
5\end{array}$ & $\begin{array}{l}17 \\
1 \\
1.5 \\
1.5\end{array}$ \\
\hline
\end{tabular}

a Examined by George Steiger. Specimens were first coated with parafin so that the specific gravity

obtained would be independent of pore space.
$b$ Determined by C. E. Lesher. Specimens had had ample opportunity to dry out, so that, with one exception, there was but slight air-drying loss at $60^{\circ} \mathrm{C}$.

A comparison of the figures shows but a slight relation between weight and ash. The figures suggest a distinct difference in the weight of Cranston coal as compared with that of Portsmouth coal. 
Sample 4, from Cranston, has a higher specific gravity than sample 2, from Portsmouth, though it contains less ash. Sample 3 has a higher percentage of ash and also higher specific gravity than sample 4. But samples 1 and 2, with the same percentage of ash, show a marked difference in specific gravity. In fact, if the specific gravity of sample 1 was obtained while it contained 17 per cent of moisture, as it seems to have been, the air-dried sample would have had a specific gravity of only 1.36, making the difference still more striking.

The sampling and testing were not complete enough to permit general conclusions to be formed with certainty, but the figures suggest, at least, that there may be differences in the specific gravity of the coal regardless of the ash. Sample 1 indicates that some of this coal when air-dried is of no higher specific gravity than other anthracite coals.

These figures for specific gravityo may be supplemented by the following figures obtained by Jackson: ${ }^{1}$

Specific gravity and ash of coal from Rhode Island and Massachusetts, according to C. T. Jackison.

\begin{tabular}{|c|c|c|}
\hline & $\begin{array}{l}\text { Specific } \\
\text { gravity. }\end{array}$ & Ash. \\
\hline 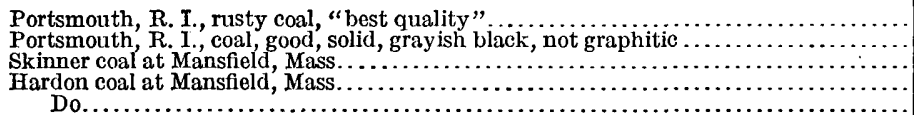 & $\begin{array}{l}1.85 \\
1.7704 \\
1.69 \\
1.71 \\
1.73\end{array}$ & $\begin{array}{l}3.235 \\
9.50 \\
6.4 \\
2.0 \\
4.0\end{array}$ \\
\hline
\end{tabular}

A. B. Emmons ${ }^{2}$ obtained 2.209 as the specific gravity of coal from the Cranston shaft, and the ash ran 13.07 per cent. The correspondence with the figure 2.20, obtained by Steiger, may be accidental, but it confirms in a measure the recent determination.

In general, it appears that Rhode Island coal is heavier for a given volume than the coals with which it competes; that the coal on the edges of the basin, where most compressed, is heavier than out in the basin, as at Portsmouth or Mansfield; and that, though these differences may be in part due to differences of percentage of ash, they appear also to be due to differences in the weight of the coal matter.

Some idea of the bearing of the specific gravity of the coal on its burning qualities may be gained from a quotation from a recent work by Porter and Durley: ${ }^{3}$

It is probable that few, if any, coals which have a specific gravity over 1.6 are worth burning and, excepting the anthracites and possibly one or two other special coals, a specific gravity of 1.52 may be taken as the approximate density of the most impure coals that can be profitably burned for commercial purposes.

\footnotetext{
1 Jackson, C. T., Report on the geologic and agricultural survey of the State of Rhode Island, Providence, 1840 .

2 Emmons, A. B., Notes on the Rhode Island and Massachusetts coals: Am. Inst. Min. Eng. Trans., vol. 13, pp. 510-517, 1885 .

3 Porter, J. B., and Durley, R. J., An investigation of the coals of Canada: Canada Dept. Mines, Mines Branch, vol. 1, p. 194, 1912.
} 


\section{CHEMICAL CHARACTER.}

The chemical composition of a coal determines its heat-giving capacity. The principal heat-giving elements of any coal are the uncombined or fixed carbon and the combined hydrogen and carbon, known as "volatile matter" or "volatile combustible." If Rhode Island coal contained only those substances it would contain about 95 per cent of fixed carbon and 5 per cent of volatile matter, or in the ratio of 19 to 1 . Pennsylvania anthracite, as shown by an average analysis of a large number of commercial samples made by the Second Geological Survey of that State, ${ }^{1}$ shows an average ratio of 22 to 1 , so that Rhode Island anthracite, when freed of water and ash, contains a little more volatile matter and a little less fixed carbon than Pennsylvania anthracite. Unfortunately, the percentage of moisture and ash in Rhode Island coal greatly exceeds that in Pennsylvania anthracite, with which it comes into competition, and, further, as discussed beyond, it is found that the volatile matter of Rhode Island coal is entirely noncombustible, consisting probably of water and carbon dioxide, so that it should, as a source of heat, be excluded from the coal and be grouped with the ash and moisture.

The average analysis of Pennsylvania anthracite referred to gives the average percentage of moisture in the commercial coal as 3.30 . The average of recent analyses of mining samples of Rhode Island coals, made by the United States Bureau of Mines, is 16 per cent for samples from Portsmouth, where the coal is mined underground, and 6.5 per cent from the open cut at Cranston. The ash in the average Pennsylvania anthracite analysis is 8.40 ; in the recent analyses of Rhode Island coal by the Bureau of Mines it.ranges from 13.76 to 33.90 , the average being 22.91 . In general, it would appear that the moisture in fresh Rhode Island coal is from two to six times as high as in Pennsylvania anthracite and the ash between two and three times as high. The possibility of reducing the moisture by drying and the ash by washing will be considered below.

As compared with the bitumino us coals that are shipped into New England, Rhode Island coal is proportionately lower in "pure coal," that is, coal without water or ash, for, though water and ash form from one-fourth to one-half of Rhode Island coal as mined, they form only one-tenth to one-twentieth of the bituminous coals from the eastern edge of the Appalachian coal field. These are the coals that are shipped into New England, but they are the highest grades of bituminous coals and do not represent bituminous coals in general. Considered commercially, however, Rhode Island coal should necessarily be compared with the coals with which it must compete.

The table on pages 26-27 gives a set of recent analyses by the Bureau of Mines of samples of Rhode Island coal taken in the mine, in accord- 
ance with the modern practice of cutting the full width of the worked portion of the bed, quartering down to a 2-pound sample, which is then hermetically sealed so that the moisture content is preserved

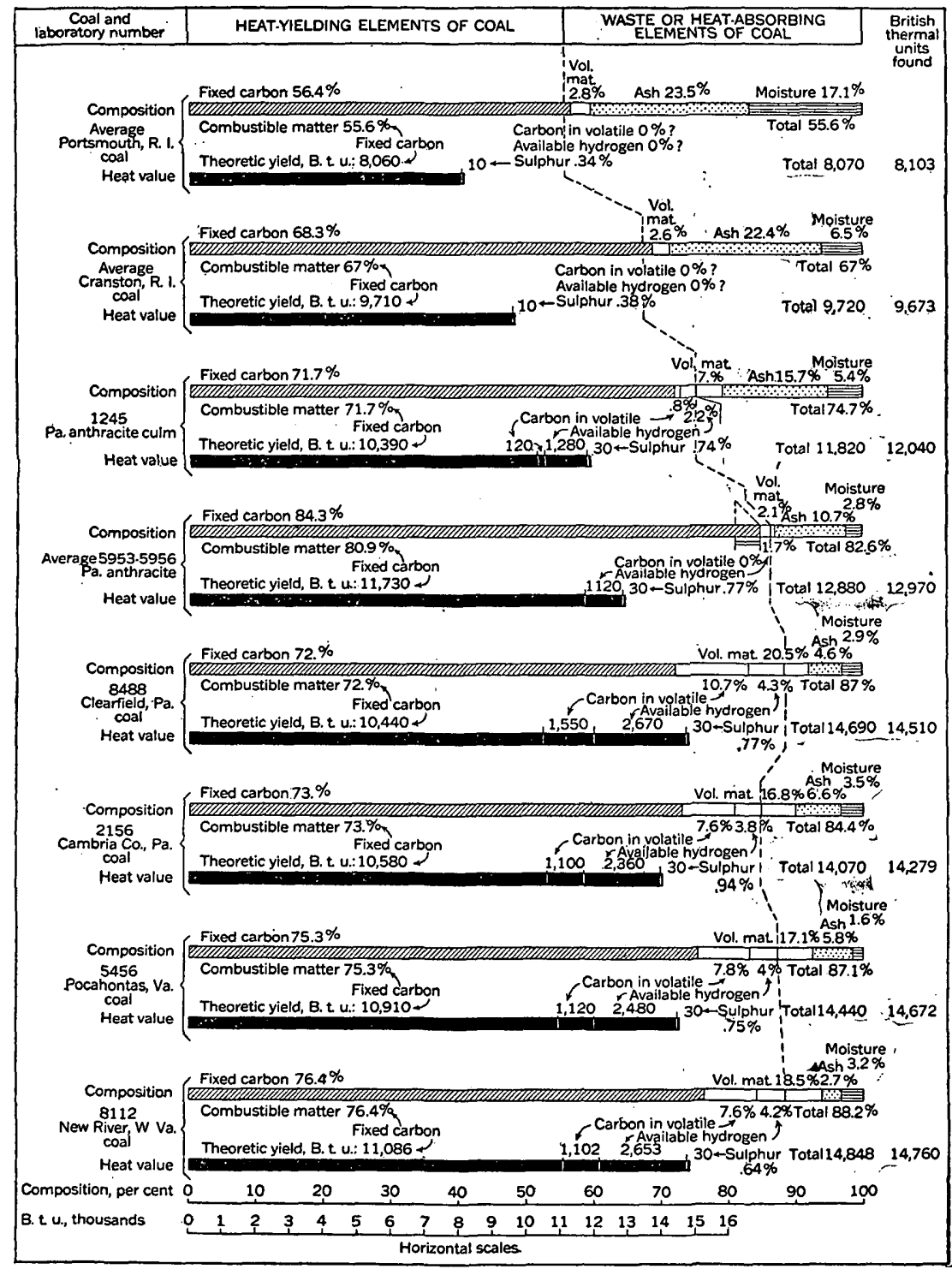

FIGURE 2.-Chart showing composition and theoretic heating power of Rhode Island coal in comparison with other coals with which it must compete in New England.

without change until analyzed. The second table gives analyses of Rhode Island coal made by the Bureau of Mines from samples taken from carload lots or from large quantities, which were tested at the laboratories of the Bureau of Mines in different ways. These 
samples have had opportunity to dry out and so show a much smaller percentage of moisture. The sample taken at Portsmouth consisted of about 20 tons of "the best that the mine can produce." In the third table are given some analyses of samples taken across the bed, or from lots of several tons each, by A. B. Emmons, and analyzed by F. A. Gooch and B. T. Putnam. ${ }^{1}$ These analyses differ from those in the first table in that the samples have more or less dried out according to the weather at the time the analysis was made. The Bureau of Mines analyses are all made on the air-dried sample. The fourth table includes some old analyses by Jackson. ${ }^{2}$ They are of interest in that they give analyses of coal from the part of the field near Mansfield. The analyses from Portsmouth form a basis for comparison. The fifth table gives a few analyses made by the Bureau of Mines from samples in the anthracite field; the fields of Jefferson County, Clearfield County, and Cambria County of Pennsylvania; the Pocahontas field of Virginia; and the New River field of West Virginia.

The chart given in figure 2 shows the relative character of Rhode Island coal in contrast with the coals just mentioned, both as to composition and heating power.

In the following tables, under "Kind," A represents a mine sample collected by an inspector of the technologic branch of the United States Geological Survey; B, a mine sample collected by a geologist of the Survey; and C, a car sample taken at the fuel-testing plant. The form of analysis is denoted by number as follows: 1 represents the sample as received; 2 , the sample dried at a temperature of $105^{\circ}$ C.; and 3, the sample free from moisture and ash according to calculation. 


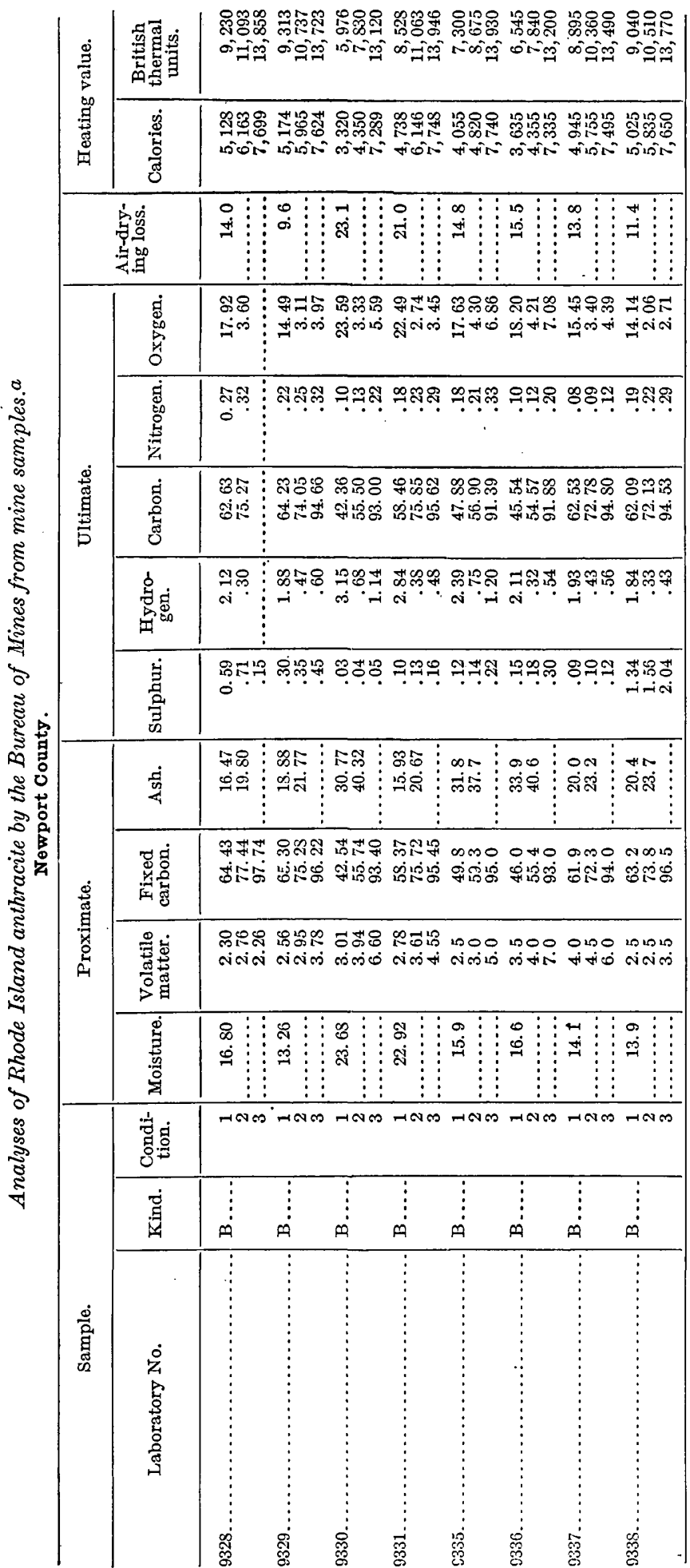

무영 题

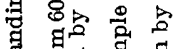

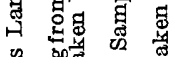

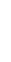

刍

घี 명

궁

O웅

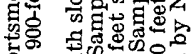

․․

क范

के

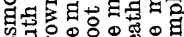

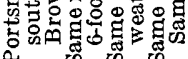

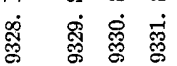




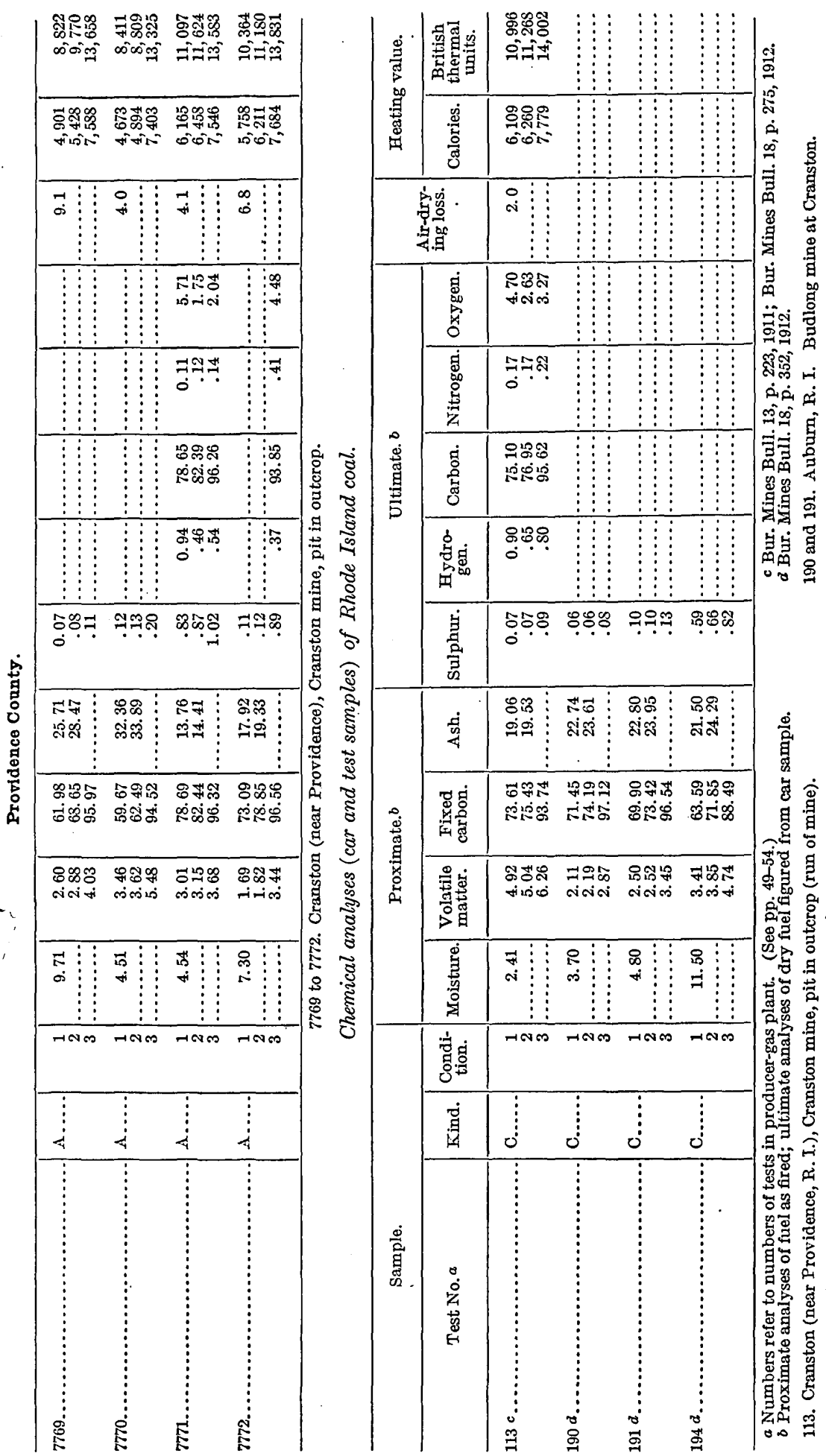




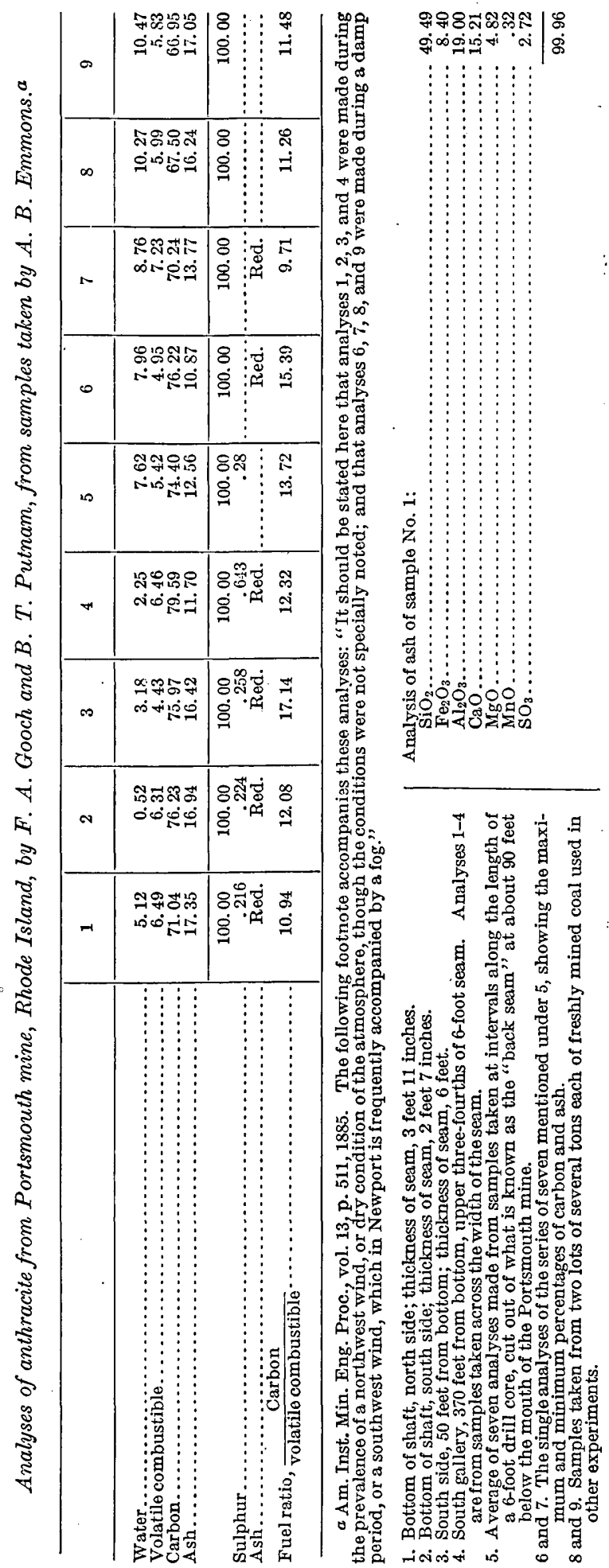


Analyses of coals from Portsmouth, $R$. I., and Mansfield, Mass., by Jackson. ${ }^{a}$

\begin{tabular}{|c|c|c|c|}
\hline$\cdot$ & $\begin{array}{l}\text { Water } \\
\text { and } \\
\text { volatile } \\
\text { matter. }\end{array}$ & $\begin{array}{c}\text { Fixed } \\
\text { carbon. }\end{array}$ & Ash. \\
\hline 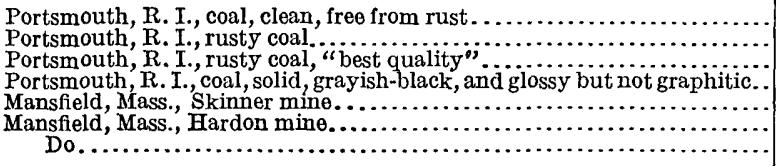 & $\begin{array}{r}10.0 \\
7.0 \\
10.5 \\
13.0 \\
6.2 \\
6.0 \\
6.0\end{array}$ & $\begin{array}{l}84.5 \\
77.0 \\
85.84 \\
77.5 \\
87.4 \\
92.0 \\
90.0\end{array}$ & $\begin{array}{l}5.5 \\
16.0 \\
3.66 \\
9.5 \\
6.4 \\
2.0 \\
4.0\end{array}$ \\
\hline
\end{tabular}

a Jackson, C. T., op. cit:

These analyses of Mansfield coal must be interpreted in the light of recent analyses of Portsmouth coal. They suggest that the coal at Mansfield has a little higher percentage of fixed carbon than that at Portsmouth and possibly is more graphitic.

Jäkson reports a comparative test for ash of Portsmouth and Lackawanna coal by Christopher Rhodes, jr. In the first test 33,477 pounds of Lackawanna coal yielded 2,566 pounds of ash, or 7.66 per cent; in the second test 32,344 pounds of the same coal yielded 2,489 pounds of ash, or 7.69 per cent. On the other hand, 8,705 pounds of Portsmouth coal yielded 1,332 pounds of ash, or 15.3 per cent. 


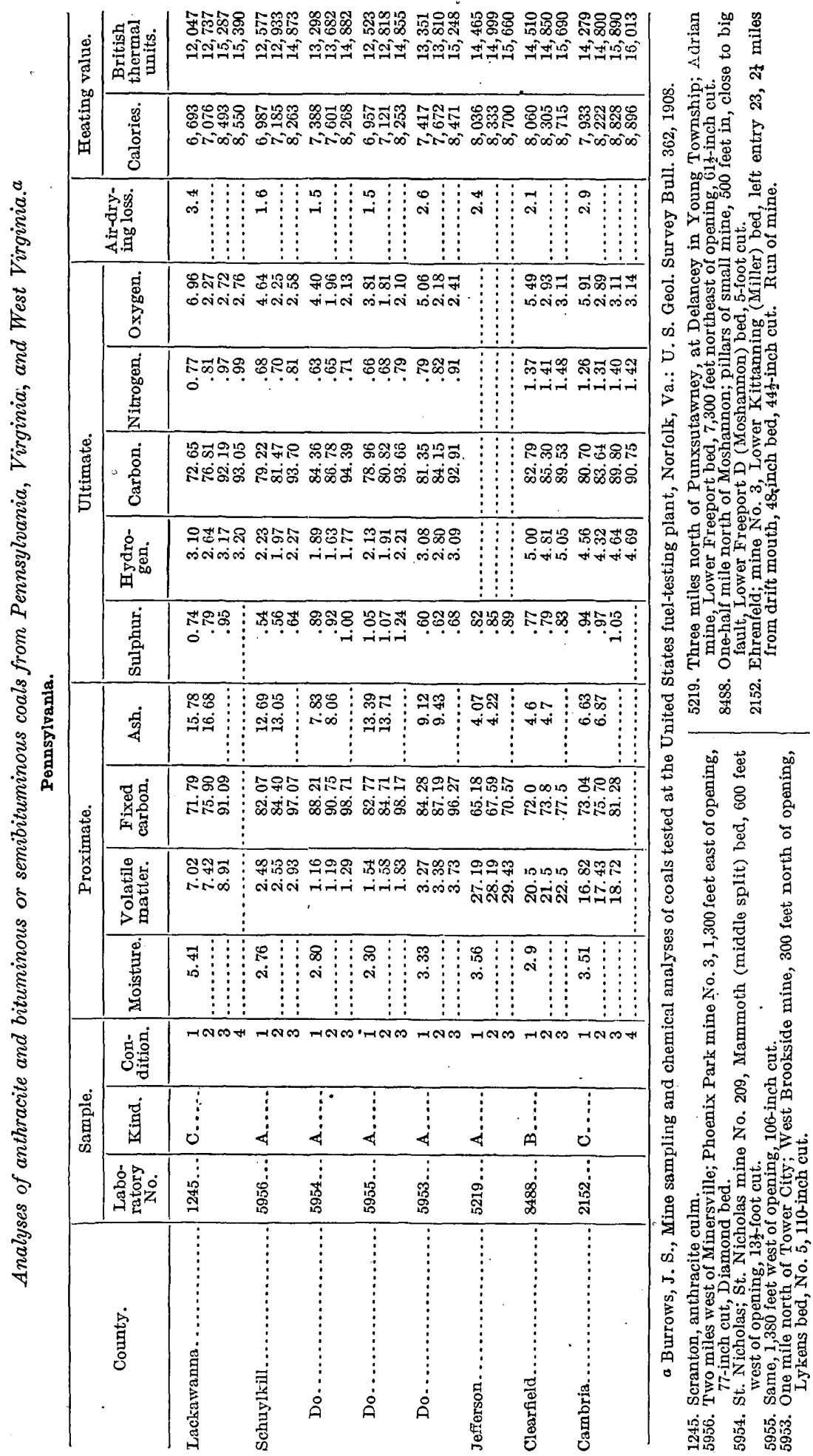




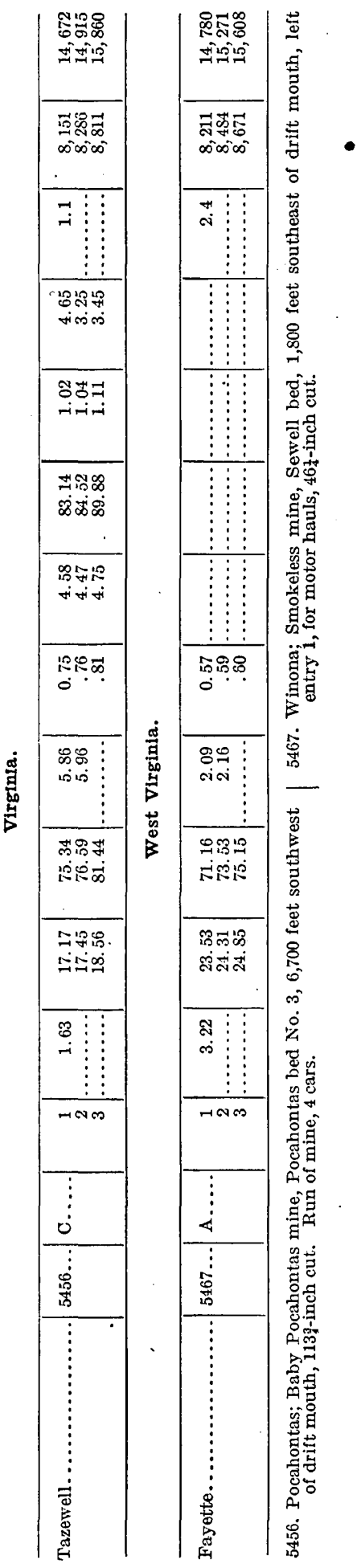


The fact that Rhode Island coal will part with or take up moisture, according as the air is dry or moist, is discussed below. (See p. 37.) The coal takes up as much as 15 per cent of moisture if it is exposed to dampness or loses most of its moisture if it is exposed to a dry wind when broken up fine. The heating value of the coal may therefore be said to range between the values given for the coal as mined and as air-dried.

As shown by the analyses, Rhode Island coal as mined ranges from less than 6,000 to more than 9,000 British thermal units where mined underground, and from less than 8,500 to more than 10,000 British thermal units if mined in open cuts, where it is possible that the coal may have dried out in part. The anthracite culm yields more than 12,000 British thermal units, and three other samples of anthracite as mined yield from 12,500 to 13,350 British thermal units. In other words, the anthracite culm shows a theoretic heating power double that of the poorest of the Rhode Island samples and one-third better than the best from underground, or about one-fifth better than the best of the open-cut samples. It would appear that in general Rhode Island coal as mined has from 60 to 70 per cent of the heating power of the bituminous coals cited, though it ranges both above and below these figures. This comparison makes it clear that Rhode Island coal, if used as fresh mined in large lumps (which can not dry out quickly), will not compare well with other coals, regardless of the furnace or other apparatus used. But if comparison is made between Rhode Island coal and other coals on the air-dried basis the result is not quite so one-sided. The other coals cited carry, as a rule, so low a percentage of moisture as mined that drying in air increases their heating qualities only a very few hundred British thermal units at the outside, whereas the drying out of Rhode Island coal may result in an increase of heating capacity of 10 to 20 per cent in the coals high in moisture and 2 to 10 per cent in the coal from Cranston.

The average of the British thermal unit determinations ${ }^{1}$ on airdricd samples of Rhode Island coal is 9,908. If sample 9330, which is labeled as "weathered;" is left out of account the average is 10,068. It may therefore be taken as a fair assumption that, on the air-dried basis, Rhode Island coal has a value of 10,000 British thermal units. On this basis it may be noted that thoroughly dried Rhode Island coal has theoretically about 75 per cent of the heating power of anthracite coal and about 70 per cent of the heating power of the high-grade bituminous coals that are brought into New England.

The analyses of Rhode Island coal given above are from samples of beds that are mined for coal and, as a rule, are from the better parts of these beds. The carbonaceous matter of the coal measures of Rhode Island grades from the best of these samples to carbonaceous 
shale containing only a very small percentage of carbonaceous matter. As already explained, where the beds have been squeezed thin, the coal has generally been changed to graphite and is accompanied by a high percentage of ash, which consists mainly of quartz, apparently deposited by water carrying silica in solution. No analyses of properly averaged samples of the more graphitic portions of the coal beds are at hand. The following analyses, however, of samples from Fenners Ledge, at Arlington, will give a fair idea of the composition of the graphite beds:

Analyses of graphite of Fenners Ledge, at Cranston, R. I. ${ }^{a}$

\begin{tabular}{|c|c|c|c|c|c|c|}
\hline & $1 b$ & $2^{b}$ & $3^{b}$ & $4 b$ & 5 & 6 \\
\hline 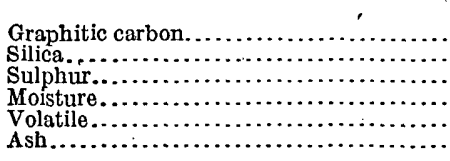 & $\begin{array}{r}47.68 \\
46.32 \\
\cdots \cdots \\
6.00 \\
\cdots \cdots\end{array}$ & 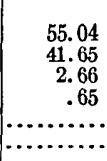 & \begin{tabular}{r}
57.17 \\
39.63 \\
2.63 \\
.57 \\
\hdashline$\ldots .$. \\
\end{tabular} & $\begin{array}{r}64.21 \\
34.08 \\
1.31 \\
.40 \\
\cdots\end{array}$ & \begin{tabular}{r}
25.27 \\
$\cdots \ldots$. \\
\hdashline$\ldots . .$. \\
7.86 \\
66.87
\end{tabular} & 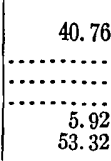 \\
\hline 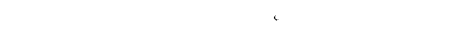 & 100.00 & 100.00 & 100.00 & 100.00 & 100.00 & 100.00 \\
\hline
\end{tabular}

a Preliminary report of the Natural Resources Survey of Rhode Island: Rhode Island Bur. Industrial Statistics Bull. 1 (Ann. Rept. 1909, pt. 3), p. 115, 1910.

$b$ Furnished by G. I. Gross.

1. By Prof. Sharples, of Boston.

2. By State Assayer Perkins, of Rhode Island.

3 . By same analyst as 2 , from later sample.

4. Latest analysis, by English.

5 and 6 . By Chase Palmer, of the U. S. Geological Survey, from samples obtained by E. S. Bastin and C: W. Brown.

This material can hardly be considered a fuel and in fact is prepared and sold for foundry facings. Though the analyses given are supposed to be from a continuation of the same bed or carbonaceous zone as that which is being mined at Cranston for coal, the material at the Fenners Ledge appears to have been much more squeezed than that at the Budlong mine, which doubtless accounts for its more graphitic character as well as its higher percentage of ash. At this point, as shown in figure 1 (p. 19) and Plate IV (p. 18), the bed is as irregular as most metalliferous ore bodies. At the G. L. Gross mine, to the south, the bed appears to be more regular, and mining has been extended about 200 feet underground.

\section{REASON FOR LOW HEAT VALUE OF RHODE ISLAND COAL.}

Attention has already been called to the high ash and high moisture content of Rhode Island coal. In sample 9328, as given in the table on page 26 , the ash and moisture together amount to 33.27 per cent of the coal, practically one-third of it. In sample 9329 they amount to 33.14 per cent; in sample 3330 to 54.45 per cent, or more than one-half, and so on. In contrast with these figures, the Pocahontas coal shown in analysis 5456 (p. 31) has only 6.49 97887 -Bull. 615-15-3 
per cent of ash and moisture together, and the New River coal (analysis 5467, p. 31) has only 5.31 per cent. Since the ash and moisture are almost if not entirely inert matter, it is evident that if the coal is made up of two-thirds coal and one-third ash and moisture, it can have only two-thirds the heating value it would have if all coal.

But there is still another factor involved. If comparison is made between Rhode.Island coal and other coals on the ash-free and moisture-free basis, it is evident that there is still a marked difference. For example, none of the Rhode Island coals on this basis reach a heat yield of 14,000 British thermal units, whereas, of the competing coals listed none go under 14,800 and the best average 16,000 British thermal units. In other words, there is a difference of 1,000 to 2,000 British thermal units in the heat value of the coaly matter or pure coal. The cause of this is fairly apparent from a further study of the analyses. It was noted above that if the moisture and ash are left out of consideration, Rhode Island coal has almost exactly the same composition as Pennsylvania anthracite; that is, about 95 per cent of fixed carbon and 5 per cent of volatile matter. Why, then, do they not have the same relative heating power?

If a study is made of the analysis of Pocahontas coal shown in the table on page 31 , sample 5456 , it may be noted that, on the ash and moisture free basis the fixed carbon is 81.44 per cent and the total carbon 89.88 per cent. Therefore, 8.44 per cent of the carbon occurs in combination with the other elements of the coal. When Pocahontas coal is heated to $500^{\circ} \mathrm{C}$., about two-thirds of the gas that is given off (water and tar having been separated out) is composed of carbon and hydrogen compounds-about one-sixth is hydrogen and the other one-sixth is carbon dioxide, carbon monoxide, and illuminants. If the temperature is raised to $1,000^{\circ} \mathrm{C}$., the gas is twothirds hydrogen, one-fourth carbon and hydrogen compounds, and the rest carbon dioxide, carbon monoxide, and illuminants. ${ }^{1}$ The hydrogen, carbon and hydrogen compounds, carbon monoxide, and illuminants are combustible. The carbon dioxide is not. In the specific tests to which reference has been made the carbon dioxide, ammonia, and water of constitution which, added together, make up the "inert volatile matter," come to only 0.7 per cent.

Now, 1 pound of carbon in burning to carbon dioxide will yield about 14,400 British thermal units. If 81.44 per cent of the coal is fixed carbon, the fixed carbon in a pound of Pocahontas coal like sample 5456 should yield 11,727 British thermal units. But the coaly matter or "pure coal" of that sample is credited with 15,860 British thermal units. Evidently the remainder must come from the burning of the volatile matter. As we have seen, the volatile matter consists almost entirely of carbon and hydrogen in combustible form.

1 Bur. Mines Bull. 1, p. 30, 1910. 
So much of the hydrogen as will come off in combination with oxygen in the form of water-that is, an amount equal to one-eighth of the oxygen-is deducted. As the oxygen amounts to 3.45 per cent, one-eighth of that or 0.43 per cent may be subtracted from 4.75 per cent of hydrogen, leaving 4.32 per cent of "available" hydrogen, as it is called: Now, 0.0844 of a pound of carbon, the amount of carbon in the volatile matter of a pound of coal under consideration, will yield $14,400 \times 0.0844$ or 1,215 British thermal units. But 1 pound of hydrogen when burned to water yields 62,048 British thermal units and 0.0432 of a pound of hydrogen, the amount in a pound of this coal, would therefore yield 2,680 British thermal units. The 2,680 and the 1,215 British thermal units added to the 11,727 British thermal units from the fixed carbon give 15,622 British thermal units, as compared with 15,860 obtained in the calorimeter test. As a matter of fact, certain elements affecting the result have not been taken into consideration in the above computation.

Similarly the analyses of anthracite coal from Lackawanna and Schuylkill counties, Pa. (analyses 1245 and 5953 to 5956, p. 30), show that apparently, though not probably, all the carbon is in the form of fixed carbon, and an analysis of the volatile matter may fail to show any hydrocarbons; but from the percentage of hydrogen and oxygen it is evident that there is still a considerable amount of "available" hydrogen left. For example, in the ash-free and moisture-free sample of anthracite culm from Lackawanna County (analysis 1245 (condition 3), p. 30), there are 3.17 per cent of hydrogen and 2.72 per cent of oxygen. As one-eighth of 2.72 per cent or 0.34 per cent of hydrogen will satisfy the oxygen, 2.38 per cent of hydrogen is left for burning. But 0.0238 of a pound, the amount of available hydrogen in a pound of that coal, will yield 1,376 British thermal units, so that the coal shows a heat value at least that much higher than that obtained from the fixed carbon alone.

In Rhode Island coal, as shown in the analyses (pp. 26-28), not only is all the carbon apparently in the form of fixed carbon but all the hydrogen is required to satisfy the oxygen, leaving none "available" for burning. In other words, on the face of it, the volatile matter of Rhode Island coal does not appear to contain any combustible matter. In fact, in most of the samples there is not enough hydrogen to satisfy the oxygen, so that some of the oxygen may be united with some of the carbon in the form of carbon dioxide. $\Lambda$ s the fixed carbon is determined by subtracting from 100 the ash, moisture, and volatile matter, and is therefore liable to include more than the carbon (for in some of these analyses it exceeds in amount the total carbon in the coal), it is probable that the volatile matter consists mainly of water and carbon dioxide and possibly some carbon monoxide. 
If all the fixed carbon in Rhode Island coal were burned it would yield a higher calorific value for the coal than is actually obtained, which indicates that the volatile matter of that coal adds nothing to its heat value, and that the "fixed carbon" contains a small amount of noncombustible matter or loses some heat in the evaporation of the contained water.

In brief, though the small amount of volatile matter in Pocahontas coal is calculated to yield about one-fourth the heat value and the volatile matter in Pennsylvania anthracite is calculated to yield about one-tenth the heat value, the rolatile matter in the Rhode Island coal appears to add little or nothing to the heat value, which

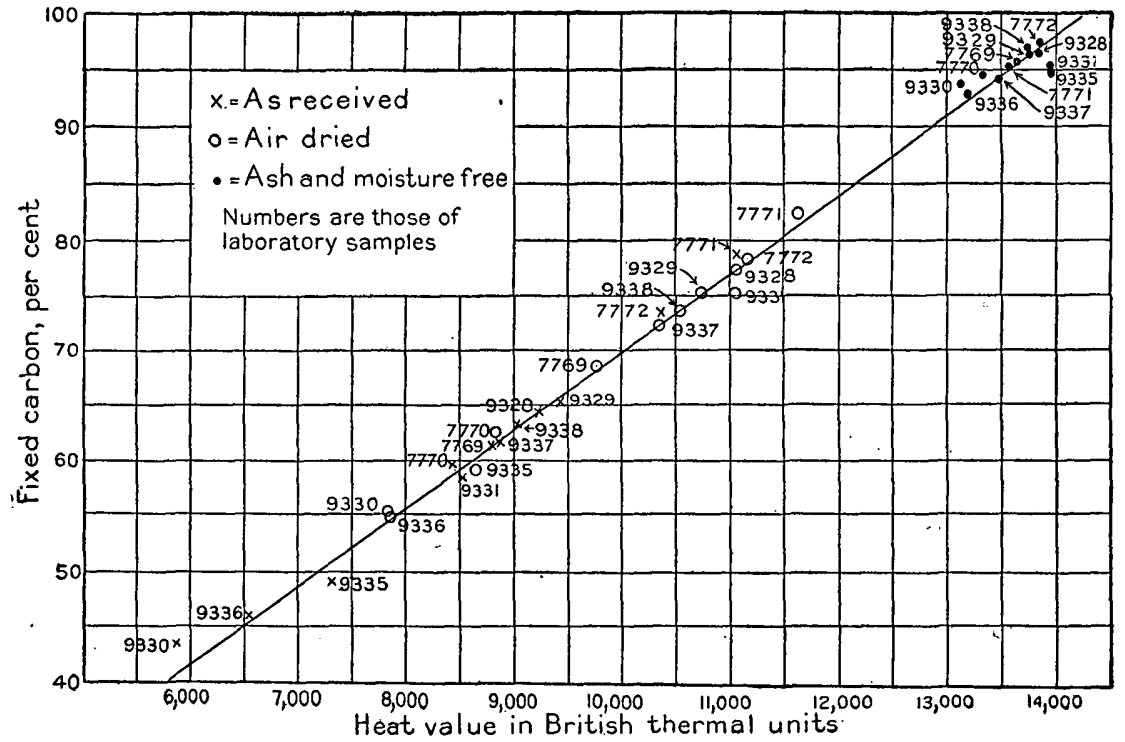

FIGURE 3.-Chart showing relation of carbon in Rhode Island coal to fuel value.

seems to be derived entirely from the fixed carbon. As a matter of fact, the calorific value of Rhode Island coal can be readily computed within probably 1 per cent by multiplying the percentage of fixed carbon by 144. Thus, if the percentage in one one-hundredth of a pound be multiplied by 14,400 , it will be found to be generally a little higher than the actual figure obtained in the calorimeter. Thus in sample 9328 (p. 26) the fixed carbon is 64.43 , and $0.6443 \times$ 14,400 gives 9,278 British thermal units, as compared with 9,230 obtained in the calorimeter. In sample 9330 (p. 26) the fixed carbon in a pound, 0.4254 , multiplied by 14,400 gives 6,025 British thermal units, as compared with 5,976 obtained in the test. In sample 9331 (p. 26) the fixed carbon should yield, by the above method of computation, 8,405 British thermal units, whereas the test gave 8,528 ; here the actual value is slightly above the value 
as computed. Figure 3 shows the relation between the fixed carbon and the British thermal unit value as determined. The chart shows first that the fixed carbon of the coal, whether from Portsmouth. or Cranston, has an almost uniform heat value and that the heat value is expressed as stated above by a little below 144 British thermal units for each per cent of fixed carbon in the coal. The line expressing the average ratio as drawn has the ratio 1:143.

\section{BEHAVIOR OF RHODE ISLAND COAL TOWARD MOISTURE.}

The presence of such a high percentage of moisture in so hard a coal has always excited a peculiar interest. In this connection it was pointed out by Emmons in 1884 that the Portsmouth coal, at least, possessed the striking peculiarity of quickly taking up a large percentage of water under a moist condition of the atmosphere and as readily parting with it under a drier condition of the atmosphere. Emmons describes the following interesting experiments conducted by Gooch: ${ }^{1}$

A sample of Portsmouth coal, *** powdered and exposed for 24 hours in the balance room during the prevalence of a northwest wind, contained after exposure water amounting to 0.65 per cent of its weight when dried at $115^{\circ}$.

The dried (at $115^{\circ} \mathrm{C}$.) coal took up during 24 hours' exposure in the balance room, while the same wind was blowing, of its own

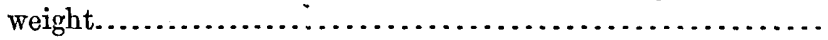

After 16 hours' exposure over water it had taken up............

After 24 hours' exposure over water it had taken up..............

After 61 hours' exposure over water it had taken up..............

After 85 hours' exposure over water it had taken up.

The percentage of water fell:

After 24 hours' exposure over $\mathrm{H}_{2} \mathrm{SO}_{4}$ to................... 1.38

After 48 hours' exposure over $\mathrm{H}_{2} \mathrm{SO}_{4}$ to.................... . 54

After 138 hours' exposure over $\mathrm{H}_{2} \mathrm{SO}_{4}$ to .................... .64

A similar sample was wet thoroughly, dried with filter paper, and exposed 24 hours in the balance room during a northwest wind. Its content of water in terms of coal dried at $115^{\circ} \mathrm{C}$. amounted to 0.75 per cent.

A sample of the drill core from Portsmouth (see analyses 5, 6, and 7, p. 28), moistened thoroughly, dried with paper, and exposed 24 hours during a northwest wind, contained, in terms of material dried at $115^{\circ} \mathrm{C} \ldots \ldots \ldots \ldots \ldots \ldots \ldots \ldots \ldots \ldots \ldots \ldots . . .61$

The dried coal took up during 24 hours' exposure in balance room.. $\quad .22$

It took up over water, in 16 hours. . . . . . . . . . . . . . . . 8.96

It took up over water, in 24 hours. . . . . . . . . . . . . . . 10.32

It took up over water, in 61 hours. . . . . . . . . . . . . . . 12.88

It took up over water, in 85 hours. . . . . . . . . . . . 13.80

1 Emmons, A. B., Notes on the Rhode Island and Massachusetts coals: A m. Inst. Min. Eng. Trans., vol. 13, pp. 512-513, 1885 . 
The coal contained of water, expressed in terms of itself dried at $115^{\circ} \mathrm{C}$.:

After 24 hours' exposure over $\mathrm{H}_{2} \mathrm{SO}_{4} \ldots \ldots \ldots \ldots \ldots \ldots \ldots \ldots \ldots . . .65$

After 48 hours' exposure over $\mathrm{H}_{2} \mathrm{SO}_{4} \ldots \ldots \ldots \ldots \ldots \ldots \ldots \ldots \ldots . \quad .53$

After 138 hours' exposure over $\mathrm{H}_{2} \mathrm{SO}_{4} \ldots \ldots \ldots \ldots \ldots \ldots \ldots \ldots \ldots . .46$

A sample of the same piece, exposed in the balance room without wetting, contained of water 0.72 per cent of the weight of the coal dried at $115^{\circ} \mathrm{C}$.

A sample of the same piece, exposed in the balance room without wetting or drying in the air bath, contained of water, expressed in terms of itself dried at $115^{\circ} \mathrm{C}$.:

Water

(per cent).

After 16 hours' exposure over water.................... 11.45

After 21 hours' exposure over water...................... 13.26

After 37 hours' exposure over water..................... 16.77

After 61 hours' exposure over water....................... 16.91

After 85 hours' exposure over water...................... 16.87

After 109 hours' exposure over water..................... 16.85

The content of water expressed in percentage of coal dried at $115^{\circ} \mathrm{C}$.:

After 24 hours' exposure over $\mathrm{H}_{2} \mathrm{SO}_{4}$, fell to................ 1.84

After 48 hours' exposure over $\mathrm{H}_{2} \mathrm{SO}_{4}$, fell to............... .83

After 138 hours' exposure over $\mathrm{H}_{2} \mathrm{SO}_{4}$, fell to............... . .71

For the sake of comparison, a piece of Pennsylvania anthracite was taken from the cellar and similarly treated.

As it came from the bin it contained of water 4.69 per cent of the weight of the coal dried at $115^{\circ} \mathrm{C}$.:

Powdered and dried $175^{\circ} \mathrm{C}$ it contained ................... (per cent).

After 26 hours' exposure over water....................... 5.91

After 75 hours' exposure over water....................... 6.34

After 144 hours' exposure over water...................... 5.10

A similar piece (i. e., not powdered), exposed over water without previous drying in air bath, contained, in terms of weight of coal dried at $115^{\circ} \mathrm{C}$.:

(per cent.)

After 30 hours' exposure over water..................... 5. 38

After 80 hours' exposure over water...................... 5.67

After 150 hours' exposure over water..................... 5.69

After 23 days' exposure over water...................... 5.38

A piece of Cumberland bituminous coal contained, as it came from the bin (the sample was powdered), in terms of the coal dried at

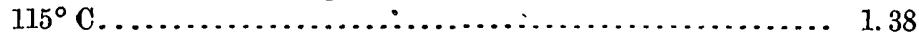

After 26 hours' exposure over water...................... 1.98

After 75 hours' exposure over water....................... 2. 06

After 144 hours' exposure over water...................... 1.95

UTILIZATION OF.RHODE ISLAND COAL. KINDS OF USE.

Rhode Island anthracite may be employed for household use, steam production, metallurgic work, briquetting, brick burning, and similar work, the manufacture of water gas or producer gas for use directly or for power production to be transmitted electrically to 
centers of distribution. The graphitic portions of the beds may be used for foundry facings and furnace linings.

Its suitability for building chimneys and other uses had been suggested at an early date, as indicated in Bryant's poem "A meditation on Rhode Island coal." Its successful household use at that time (before 1832) is indicated by the beginning of the poem:

I sat beside the glowing grate, fresh heaped with Newport coal.

That the difficulties of its burning had been fully appreciated are also indicated toward the end of the poem, where he says:
Thou shalt be coals of fire to those that hate thee,
And warm the shins of all that underrate thee;
Yea, they did wrong thee foully-they who mocked
Thy honest face, and said thou wouldst not burn;
Of hewing thee to chimney pieces talked,
And grew profane, and swore, in bitter scorn,
That men might to thy inner caves retire,
And there, unsinged, abide the day of fire.

\section{HOUSEHOLD USE.}

Rhode Island coal has always been used in a small way for household heating and some householders are said to have used it for 40 years or more. Samuel Sanford, who was well acquainted with the Portsmouth mines in the seventies, says that Portsmouth coal was then selling at the mine at $\$ 3.50$ a ton and that a small amount was purchased and hauled away for household use, but that 90 per cent of the people living. in the neighborhood preferred to burn Pennsylvania anthracite, costing at that time from $\$ 5.50$ to $\$ 7.50$ a ton. This condition has apparently prevailed during the whole history of the field.

In burning the coal is said to ignite very slowly and to snap violently and explode, tending to throw pieces of the coal out of the fire, but when once well ignited it burns very much like anthracite and gives an intense heat. The ash is said to have almost the same bulk as the coal and as a rule to fuse and clinker badly. The intense heat is said to be destructive to stoves and utensils and the clinkering tends to destroy the grate bars. Probably as a result of this rapid burning it is said to burn itself out quickly and to require much more attention in firing and in keeping overnight than other coals.

It is said that by breaking the coal down fine and carefully screening it to remove dust it ignites more easily, as it will after thoroughly drying, which also prevents the snapping of the coal when first heated.

The existence of films of graphite in the coal along planes of slipping has been thought to be partly the cause of the slow ignition of the more graphitic coal. The breaking up of this coal aids in its ignition, it is supposed, by allowing freer passage of the heat. 
In general, as compared with other anthracites and bituminous coals, as shown both by the tests in the laboratory and under the furnace, Rhode Island coal has only from 70 to 80 per cent of the heating power of other anthracites and from 60 to 70 per cent of the heating power of bituminous coals shipped into New England. Indeed, the poorer samples of Rhode Island coal show only about 40 per cent of the heating efficiency of competing coals. This fact, together with its slower ignition, its destructively hot fire, and the fact that it yields a maximum of eight times as much ash as competing coals and requires more frequent attention, fully explains its unsuccessful use for household heating in the past. It is the misfortune of Rhode Island coal that it must compete with the best coals of the United States, which are brought into its market by boat at very low rates.

At least two attempts have been made to briquet Rhode Island coal commercially, both of them by the Zwoyer process. Apparently neither attempt proved successful. Whether the process or the binder had anything to do with the lack of success is not known. It is claimed that the briquets first made, in 1898, fell to pieces, owing to the binder burning out before the coal became ignited, and the briquets made recently are said to have yielded dense volumes of smoke and soot that soon clogged the flues and chimneys. It may be doubted whether any of the binders in common use to-day will prove satisfactory in the household stove, in which the temperature is relatively low as compared with that of the furnaces under steam boilers for power. Experiments have since been made at Portsmouth, and the results of tests by the Bureau of Mines indicate that it will be possible to make briquets that will be practically smokeless and that will stand handling. It appears possible that experiments will develop a process of making briquets, probably with some admixture of a high gas coal, that will give at least fairly successful results in household use.

The experiments published by the Bureaiu of Mines were made at St. Louis in 1906 by what was then the technologic branch of the United States Geological Survey. No test was made of Rhode Island coal alone, but two tests were made of that coal mixed with two different bituminous coals from Pennsylvania in the form of briquets. The manufacture and character of the briquets is described under the heading "Briquetting tests" (pp. 46-48). The tests were made on a sectional steam boiler, such as is in common use for house heating. The detailed results of these tests are given in Bulletin 27 of the Bureau of Mines. The economic results only are repeated here. For the sake of comparison there are also given the results obtained by similar tests made in the engineering laboratory of the University of Illinois, at Urbana, Ill., on anthracite, coke, and Pocahontas coal. 
Results of tests of briquetted fuels in house-heating boilers at St. Louis, Mo., and - Urbana, Ill.

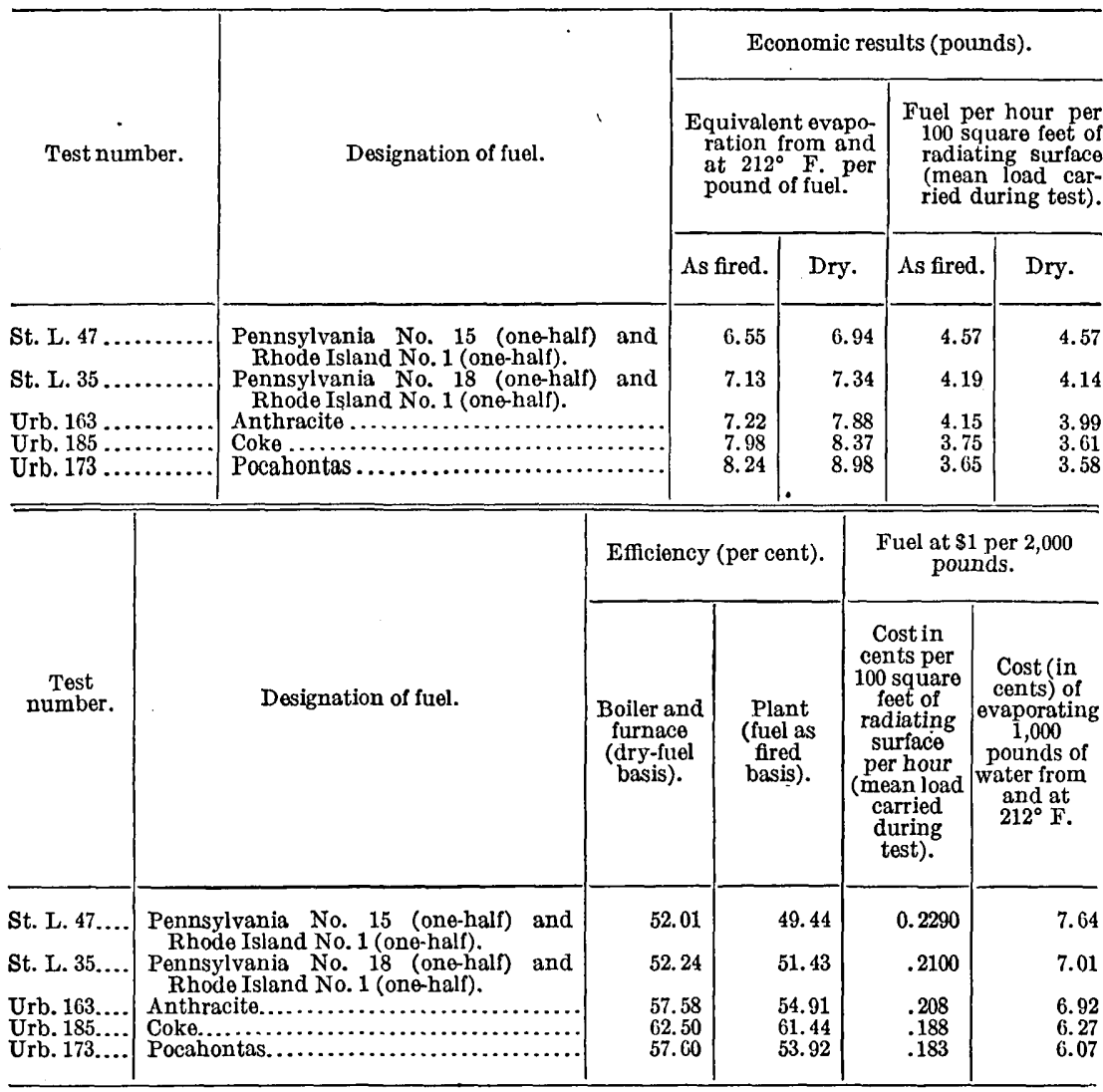

\section{As far as the experiments were conducted it was-}

shown that the pitch binders used are not suitable for the furnace working at the low temperatures common in the household boiler, as they volatilize and in most cases escape unburned or were deposited on the surface of the boiler. This coating generally burned off once or twice a day, causing a high temperature in the flue and, as a consequence, danger of fire. ${ }^{1}$

A test of "treated Rhode Island coal" by the Bureau of Mines, though not conclusive, failed, it is said, to show improvement in the burning or heating qualities of the coal.

\section{USE IN STEAII RAISING.}

The same qualities of the coal that are shown by household use are evident in its use in steam raising. (See description of action on grate in test 401, p. 45.) In this use its heat-giving value is of prime importance. The tests of the calorimeter show Rhode Island coal to

I Snodgrass, J. M., Fuel tests of house-heating boilers: Univ. Illinois Bull. 31, 1909. 
have from 40 to 80 per cent of the heating value of competing coals. A number of careful commercial tests have been made, for one of which the general results are available;

In 1874 a test of the Cranston coal was made at the pumping station of the Providence Waterworks. Unfortunately a table giving the detailed figures for the run has been lost, but the report which accompanied the table is still available. The following extracts from the report, a copy of which was furnished by the city engineer's office, give the most complete and satisfactory demonstration of the steaming qualities of the coal that has been found. The report in part is as follows:

\section{CRANSTON COAL.}

The Cranston coal used at Pettaconset is a lusterless anthracite, containing graphite, quartz, and traces of asbestos and sulphur among its impurities. It yields about 26 per cent of ash. Its specific gravity is 2.30 and weight 64.75 pounds (? 133.75 pounds) to the cubic foot. Its evaporation power is about 7.76 pounds of water from and at $212^{\circ}$ per pound of coal, which is the same as 6.6 pounds of water from $60^{\circ}$ to steam at 60 pounds.

The Lackawanna coal is a brilliant anthracite, containing about 18 per cent of ash. Its specific gravity is 1.60 and weighs 52.82 pounds (? 99.8 pounds) to the cubic foot. Its evaporative power is about 10.74 pounds of water from and at $212^{\circ}$ per pound of coal, which is the same as 9.10 pounds of water from $60^{\circ}$ to steam at 60 pounds.

The evaporative power of the Cranston coal is therefore about 72 per cent of the Lackawanna.

\section{The following explanation of the lost table is given:}

Line 7. Rate of delivery is based upon the number of strokes during the run or experiment, length of stroke as observed, and a deduction of $2 \frac{1}{2}$ per cent from the theoretical discharge of the pump. This percentage of loss is established by repeated weir measurements during former experiments. * * *

Line 22. The rate of combustion is based on the coal used during the experiment.

Line 23. In making up the total amount of fuel used during the day a small amount of coke was charged as Lackawanna coal, and the wood as equal to one-half its weight of coal.

Lines 24 and 25 are placed in juxtaposition to show the large amount of coal used in banking.

Line 26. The percentage of ash is made up from the total fuel used during the day. It was dampened and weighed wet and so given in the table. The Lackawanna ash was found to weigh 78 per cent of the recorded weight when dry. The Cranston ash $95 \frac{1}{2}$ per cent.

Lines 27 and 28. The water evaporated per pound of coal or combustible is based on the fuel recorded during the run or experiment, and is probably too large by so much as the coal charged to the run is too little.

The figures previously given as the evaporative power, viz, 7.76 and 10.74, are a mean of the quantity evaporated during the run and during the day per pound of combustible. The water was measured with a meter, said meter being tested before and after the experiment and proper correction made.

Line 29 is added as a check upon the quantity of water used during the different days. It will be observed that it was nearly uniform.

Line 30. The length of stroke is a mean of quarter-hourly observations. 
Line 31. The duty is based upon the theoretical discharge of the pump and the static head. While this does not give the engine full credit for its work for this trial, it was considered the least.liable to error. It may be added, however, that other experiments have shown the friction head for pump, main, and check valves to be about 3.9 per cent of static head. ** *

Line 35 is given to show the relative duty based upon the coal used during the day or week, which is probably the truest criterion of the value of the coal. Line 32 , on column $R$, is taken as unity as a fair standard of comparison.

It will be observed that columns $\mathrm{M}$ and $\mathrm{N}$ show the value of the Cranston coal about 72 per cent of the Lackawanna.

Line 36 makes the basis of comparison with the water evaporated daily, but a mean was obtained as previously explained, viz, 72 per cent, which seems to agree with the duty, as it should.

About 10 per cent of Lackawanna coal and a small portion of coke was used with the Cranston coal, to aid the fire when burning irregularly on the grate. Less of this was used as experience was gained in its use. It is probable that with care and skill no other coal need be used in connection with it. A large loss was due to the small coal, partially burned, falling through the grate; although an occasional effort was made to sift it and reuse it, no practical gain was made.

It was thought that a slower rate of combustion would be favorable to the coal, and permission was given to the agent for the coal to burn it slower. January 28th and 29 th, it will be observed, it was reduced a little, and a slight increase of duty obtained; but it seems that this diminished rate of combustion as recorded is probably in part due to screenings of small coal deducted from the coal charged and also deducted from the ash, thus reducing the ash very much for those two days, but increasing it proportionately the next day. However, a slight increase of duty is seen for the 10-days' run, where the rate of combustion is 10.16 pounds of coal per square foot of grate per hour over the first week's run, where it was 10.56 pounds.

As it was the effort of the agent to keep the engine up to the usual speed, and with very good result, it was necessary to increase the rate of combustion over the usual rate, viz, 7.30 pounds, in order to effect it. It seems very probable that a slower rate than was used would be advantageous.

Steaming tests of Rhode Island coal from Cranston have been made by the United States Geological Survey and the Bureau of Mines on the coal alone and briquetted with other high volatile coals. Results of these tests are as follows:

RHODE ISLAND NO. 1.1

Anthracite graphitic coal from Cranston, Providence County (near Providence), was designated Rhode Island No. 1. This sample was mined from surface workings at Cranston and commercially would be classed as run-of-mine coal. It was shipped under the inspection of J. S. Burrows and was used in making steaming test 401; also mixed with Utah No. 1 in steam tests (on briquets) 414 and 415, coking tests 141 and 157, and briquetting test 127; mixed with Utah No. 2 in steaming test 416 (on briquets) and briquetting test 133; mixed with Pennsylvania No. 15 in briquetting test 184; and mixed with Pennsylvania No. 18 in briquetting test 243.

1 Holmes, J. A., in charge, Report of the United States fuel-testing plant at St. Louis, Mo.: U. S. Geol. Survey Bull. 332, pp. 223-224, 1908. 


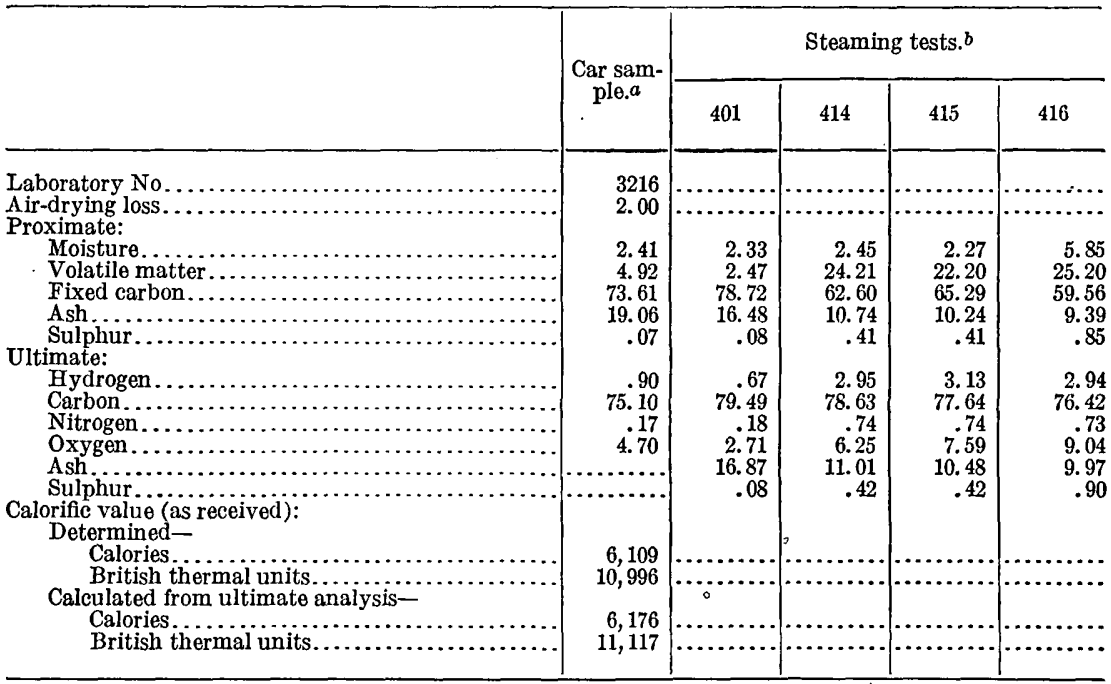

$a$ Sample from producer-gas test 113 (failure) treated as car sample.

$b$ Proximate analysis of fuel as fired; ultimate analysis of dry fuel figured from car sample.

Steaming tests of Rhode Island No. 1 (briquets).

\begin{tabular}{|c|c|c|c|c|}
\hline . & Test 401. & Test 414. & Test 415 . & Test 416. \\
\hline $\begin{array}{l}\text { Duration of test } \\
\text { Heating value of fuel............. } \mathrm{B} . \mathrm{t} \text {. u. per pound dry fuel... }\end{array}$ & $\begin{array}{r}8.05 \\
11,639\end{array}$ & $\begin{array}{r}5.0 \\
12,845\end{array}$ & $\begin{array}{r}5.0 \\
12,823\end{array}$ & $\begin{array}{r}10.02 \\
12,244\end{array}$ \\
\hline Force of draft: & 0.54 & 0.67 & 0.62 & 0.58 \\
\hline 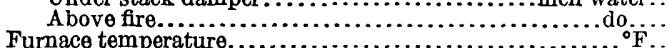 & $(a)^{.18}$ & .21 & $\begin{array}{r}0.06 \\
2, i 19\end{array}$ & $\begin{array}{r}.00 \\
2.053\end{array}$ \\
\hline $\begin{array}{l}\text { Dry fuel used per square foot of grate surface, per hour... } \\
\text { Equivalent water evaporated per square foot of water-heating }\end{array}$ & 20.22 & 18.42 & 19.01 & 21.51 \\
\hline surface per hour $\ldots \ldots \ldots \ldots \ldots \ldots \ldots$ pounds.. & 1. 99 & 2.96 & 3.25 & 2.78 \\
\hline $\begin{array}{l}\text { Percentage of rated horsepower of boiler developed............... } \\
\text { Water apparently evaporated per pound of fuel as fired.pounds.. }\end{array}$ & 55.8 & 83.0 & 91.0 & 78.0 \\
\hline Water evaporated from and at $212^{\circ}$ F.: & & & 1.17 & 4.20 \\
\hline 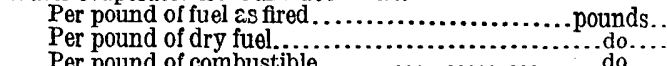 & $\begin{array}{l}4.81 \\
4.93 \\
7.70\end{array}$ & $\begin{array}{l}7.86 \\
8.05 \\
9.35\end{array}$ & $\begin{array}{l}8.36 \\
8.55 \\
0.75\end{array}$ & $\begin{array}{l}4.95 \\
5.26 \\
770\end{array}$ \\
\hline $\begin{array}{l}\text { Efficiency of boiler, including grate..... } \\
\text { Fuel as fired: }\end{array}$ & 40.91 & 60.52 & 64.39 & 41.49 \\
\hline Per indicated horsepower hour.. & 5.88 & 3.60 & 3.38 & 5.71 \\
\hline $\begin{array}{l}\text { Per electrical horsepower hour.. } \\
\text { Drv fuel. }\end{array}$ & 7.26 & 4.44 & 4.18 & 7.05 \\
\hline $\begin{array}{l}\text { Dry fuer: } \\
\text { Per indicated horsepower hour. }\end{array}$ & 5.74 & 3.51 & 3.31 & 5.38 \\
\hline Per electrical horsepower hour. & 7.08 & 4. 34 & 4.08 & 6.64 \\
\hline
\end{tabular}

a Too low to be read with Wanner optical pyrometer. Forced draft used on this test.

Remarks: Tests 414 and 415 on briquets made from Rhode Island No. 1 and Utah No. 1 mixed. The briquets burned freely, with short, yellow flame; did not crack open, but coked throughout and held together well. No smoke; burned very much like anthracite, except for color of flame. These comparative tests on Rhode Island coal No. 1 gave only 55.8 per cent capacity and were unsatisfactory. (See test 401 above.) Heavy clinker, which was tough and plastic when hot and brittle when cold, but did not stick to the grate.

Test 416 on briquets from test 133, made from Rhode Island No. 1 and Utah No. 2 mixed. With natural draft the briquets burned with a very short flame; with forced draft they burned with a longer flame, giving a hotter fire. Briquets did not coke or hold together well in the fire. No smoke; see briquetting test 127 for comparative data. No clinker; a large amount of ash resulted, due to the crumbling of the briquets and the falling of the loose particles through the grate. 
In Bulletin 23 of the Bureau of Mines the following additional data are given on page 179 for test 401 and on page 191 for tests 414 to 416 :

Test No. 401 (No. 1).-The coal burned slowly, with a short, bluish flame. It became hot and fused together, cutting off the air supply through the grate. Hooking the fire helped slightly. Small pieces of coal burned more completely than large ones. About three-fourths inch coal would be the best size for steaming purposes. Large pieces burn only on the surface, because the ash fuses and adheres to the coal, thus insulating the inner portion. Low capacity was developed, owing to the fact that high enough draft could not be obtained with the fan blower. In order to develop the rated capacity, a draft of 3 to 4 inches of water would be necessary. A rocking grate would be preferable to a flat grate. Pressure was used in the ash pit. Automatic air admission was not operated. The furnace temperature was too low to be read by the Wanner optical pyrometer.

Test No. 414 (briquets).-One-quarter of the observations of furnace temperature were too low to be read by the Wanner optical pyrometer. The average is not representative of the test. The briquets did not crumble in the fire and burned with a short flame. Automatic air admission was not operated. A heavy layer of plastic clinker formed on the grate. It was broken with some difficulty.

Test No. 415 (briquets).-The briquets did not crumble in the fire and burned with a short flame. Automatic air admission was not operated. A heavy layer of plastic clinker formed on the grate. It was broken with some difficulty. Forced draft was used.

Test No. 416 (briquets).-The briquets crumbled in the fire, did not cake, and burned with a long flame. Automatic air admission was not operated. A large amount of free ash formed on the grate. It was easily removed. Forced draft was used.

For the sake of comparison there are given below figures from the tests by the Bureau of Mines at St. Louis, Mo., and at Norfolk, Va., showing, first, the horsepower developed and, second, the pounds of water evaporated per pound of fuel of Rhode Island coal on the one hand and of some of the competing coals on the other.

Results of steaming tests by the Bureau of Mines on Rhode Island coal and other coals that are shipped into New England.

\begin{tabular}{|c|c|c|c|c|c|}
\hline $\begin{array}{l}\text { Bureau of Mines } \\
\text { designation. }\end{array}$ & Coal. & Location. & $\begin{array}{l}\text { Kind of } \\
\text { sample. }\end{array}$ & $\begin{array}{l}\text { Horso- } \\
\text { power } \\
\text { developed } \\
\text { on test. }\end{array}$ & $\begin{array}{l}\text { Pounds of } \\
\text { water } \\
\text { evaporated } \\
\text { per pound } \\
\text { of fuel } \\
\text { equivalent } \\
\text { from and } \\
\text { at } 212^{\circ} \mathrm{F} \text {. }\end{array}$ \\
\hline 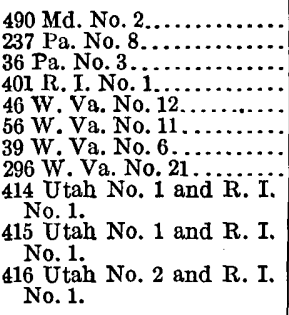 & 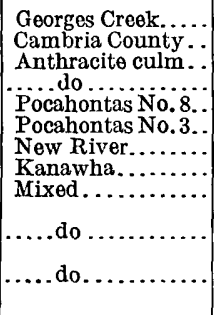 & 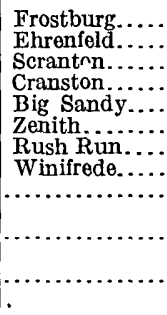 & 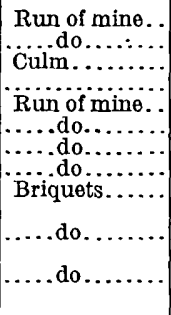 & $\begin{array}{l}239.2 \\
174.2 \\
184.5 \\
117.1 \\
206.1 \\
213.7 \\
213.2 \\
213.8 \\
174.3 \\
191.2 \\
163.7\end{array}$ & $\begin{array}{l}9.87 \\
9.85 \\
8.01 \\
4.81 \\
9.74 \\
9.54 \\
9.88 \\
9.69 \\
7.86 \\
8.36 \\
4.95\end{array}$ \\
\hline
\end{tabular}


According to these figures, Rhode Island coal alone yields from 54 to 68 per cent as much horsepower as the other coals listed and from 48 to 60 per cent as many pounds of water evaporated per pound of fuel. Lest it be thought that the highest figures have been selected for the competing coals, it may be mentioned that in other tests Pocahontas coal developed horsepower as high as 268 and New River coal as high as 367. As 20 tons of coal was used and every effort was made that the coal should be representative of that being regularly mined, the results may be accepted as accurate. As the car sample analysis of this coal (p. 44) shows it to have been above rather than below the average, it may be safely stated that, judged by analyses, calorimeter tests, and tests in actual practice, Rhode Island coal in making steam will yield from 40 to 80 per cent as many heat units as the coals with which it must compete to-day.

\section{USE IN METALIURGY.}

Rhode Island coal has been used successfully in the reduction of copper ore and in the metallurgy of iron, as already stated under the heading "History of development." At the time of its successful use anthracite coal was used in the blast furnace and the furnaces were much smaller than at present. To-day coke has been substituted for anthracite and is being used exclusively. The furnaces have been enlarged both in size and output. No figures are at hand which would form the basis for a comparison of the availability of Rhode Island anthracite as compared with coke in the modern furnace, but a general consideration of the reasons for the use of coke in the modern furnace and its cost would suggest that Rhode Island coal could not compete with coke either in cost or availability. It is quite possible that for foundry use and in small reheating furnaces, under certain conditions, it might be still possible to use Rhode Island coal in spite of the cost.

\section{BRIQUETTING TESTS.}

In addition to the actual commercial tests of Rhode Island coal when made into briquets, the Bureau of Mines has made a number of briquetting tests with that coal. ${ }^{1}$ The analyses of the coal used, both alone and mixed, will be given first, as none of the tests were made on the Rhode Island coal alone. Rhode Island No. 1 was from Cranston; Pennsylvania No. 15 was B or Miller coal from Wehrum, Indiana County; Pennsylvania No. 18 was the same coal from Lloydell, Cambria County; Utah No. 1 was from Huntington Creek, Carbon County; Utah No. 2 was from Coalville, Summit County. 
Analyses of coals used in briquetting tests.

\begin{tabular}{|c|c|c|c|c|c|c|c|c|c|}
\hline - & $\begin{array}{l}\text { R. I. } \\
\text { No. 1, } \\
\text { car } \\
\text { sam- } \\
\text { ple. }\end{array}$ & $\begin{array}{c}\text { Pa. } \\
\text { No. 15, } \\
\text { car } \\
\text { sam- } \\
\text { ple. }\end{array}$ & $\begin{array}{c}\text { Pa. } \\
\text { No. } 18, \\
\text { car } \\
\text { sam- } \\
\text { ple. }\end{array}$ & $\begin{array}{c}\text { Utah } \\
\text { No. 1, } \\
\text { car } \\
\text { sam- } \\
\text { ple. }\end{array}$ & $\begin{array}{c}\text { Utah } \\
\text { No. 2, } \\
\text { car } \\
\text { sam- } \\
\text { ple. }\end{array}$ & $\begin{array}{c}\text { Half } \\
\text { R.I. } \\
\text { No. 1, } \\
\text { half } \\
\text { Pa. } \\
\text { No. 15. }\end{array}$ & $\begin{array}{c}\text { Half } \\
\text { R.I. } \\
\text { No. 1, } \\
\text { half } \\
\text { Pa. } \\
\text { No.18. }\end{array}$ & $\begin{array}{l}\text { Half } \\
\text { oR. I. } \\
\text { No.1, } \\
\text { half } \\
\text { Utah } \\
\text { No. } 1 .\end{array}$ & $\begin{array}{l}\text { Fralf } \\
\text { R.I. } \\
\text { No.1, } \\
\text { half } \\
\text { Utah } \\
\text { No. } 2 .\end{array}$ \\
\hline Laboratory No. & 3216 & 4082 & 4509 & 3199 & 3259 & 4913 & & & \\
\hline $\begin{array}{l}\text { Air-drying loss................ } \\
\text { Proximate: }\end{array}$ & 2.00 & 2.80 & 4.10 & 3.80 & 2.30 & $\ldots \ldots \ldots$ & $\cdots$ & $\cdots$ & \\
\hline Moisture.... & 2.41 & 3.13 & 4.46 & 6.05 & 12.66 & 0.74 & 1.34 & 2.45 & 5.85 \\
\hline Volatile matter.......... & 4.92 & 17.61 & 15.44 & 42.02 & 38.30 & 15.96 & 16.39 & 24.21 & 25.20 \\
\hline Fixed carbon............ & 73.61 & 69.45 & 71.63 & 47.06 & 43.19 & 69.71 & 70.34 & 62.60 & 59.56 \\
\hline Ash $\ldots . . . \ldots \ldots \ldots \ldots$ & 19.06 & 9.81 & 8.47 & 4.87 & 5.85 & 13.59 & 11.93 & 10.74 & 9.39 \\
\hline $\mathrm{Su}$ phur................... & .07 & 3.77 & 1.49 & .55 & 1.39 & 2.61 & 1.37 & .41 & .85 \\
\hline $\begin{array}{l}\text { Ultimate: } \\
\text { Hydrogen. }\end{array}$ & & 4 f? & & & & & & & \\
\hline $\begin{array}{l}\text { Hydrogen . . . . . . . } \\
\text { Carbon........ }\end{array}$ & 75.90 & $\begin{array}{r}4.62 \\
76.41\end{array}$ & $\begin{array}{r}4.80 \\
77.43\end{array}$ & $\begin{array}{r}5.76 \\
72.32\end{array}$ & & $\begin{array}{r}3.05 \\
77.48\end{array}$ & $\begin{array}{r}3.46 \\
77.79\end{array}$ & $\begin{array}{r}2.95 \\
78.63\end{array}$ & $\begin{array}{r}2.94 \\
76.42\end{array}$ \\
\hline Nitrogen.......... & .17 & 1.14 & 11.28 & 1.38 & & $\begin{array}{r}.49 \\
.49\end{array}$ & .53 & .74 & $\begin{array}{r}10.42 \\
.73\end{array}$ \\
\hline Oxygen.... & 4.70 & 4.25 & 6.53 & 15.12 & & 2.65 & 4. 74 & 6.25 & 9.04 \\
\hline 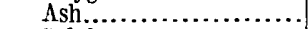 & $\ldots \ldots$ & & & & & 13.70 & 12.09 & 11. 01 & 9.97 \\
\hline Sulphur............... & & & & & & 2.63 & 1.39 & .42 & .90 \\
\hline $\begin{array}{l}\text { Calorific value (as received): } \\
\text { Determined- }\end{array}$ & & & & & & & & & \\
\hline Calories............. & 6,109 & 7,664 & 7,601 & 7,300 & & & & & \\
\hline $\begin{array}{l}\text { British thermal units } \\
\text { Calculated from ultimate }\end{array}$ & 10,996 & 13,795 & 13,682 & 13,151 & & & & & \\
\hline $\begin{array}{l}\text { analyses- } \\
\text { Calories................ }\end{array}$ & 6,176 & & & 7,189 & & & & & \\
\hline British thermal units & 11,117 & & & 12,940 & & & & & \\
\hline
\end{tabular}

\section{The briquets are thus described. (See also pp. 43-44.)}

Test 184.-Pennsylvania No. 15 was mixed with an equal portion of Rhode Island No. 1 (run of mine) in this test. Excellent briquets were made with 6.25 per cent binder on the Renfrow machine. Although the pitch used had a low melting point, the briquets handled well from the machine, and piled without sticking. The outer surface was very hard and smooth, and broke without crumbling, giving a smooth fracture and sharp edges.

Test 248.-Equal parts of Pennsylvania No. 18 and Rhode Island No. 1, both run of mine. An effort was made to improve the burning qualities by increasing the melting point of the binder, but owing to the hardness of the pitch used and insufficient pressure, these briquets were not satisfactory. They could not be handled when warm without many being broken, but when cold were brittle, producing considerable slack in handling. No physical tests were made.

Test 127 (Utah No. 1 with Rhode Island coal No. 1).-This test was made to prove the value of briquetting a good fuel with one that is commercially worthless. A highvolatile coal, low in ash, was chosen to mix with the graphitic coal. Various percentages were tried, but 47 per cent of each coal and 6 per cent binder made an entirely satisfactory briquet. Six per cent binder made excellent briquets; outer surface smooth and polished and very hard; briquets broke without crumbling, and broken surfaces were smooth and hard.

Test 139 (Utah No. 1 and Rhode Island No. 1).-In this test Rhode Island No. 1, the only available high-volatile (carbon?) coal, was chosen in order to supplement the data of test 127. Test 133 was not successful, as coal showed characteristics of lignite, both in briquetting and burning. The mixture contained 47 per cent of each coal. Briquets with 6 per cent binder were tough and hard; outer surface smooth and very hard; the fracture rough but clean and firm. No drop tests were made. 
The tests of the briquets gave the following results:

Results of tests of briquets.

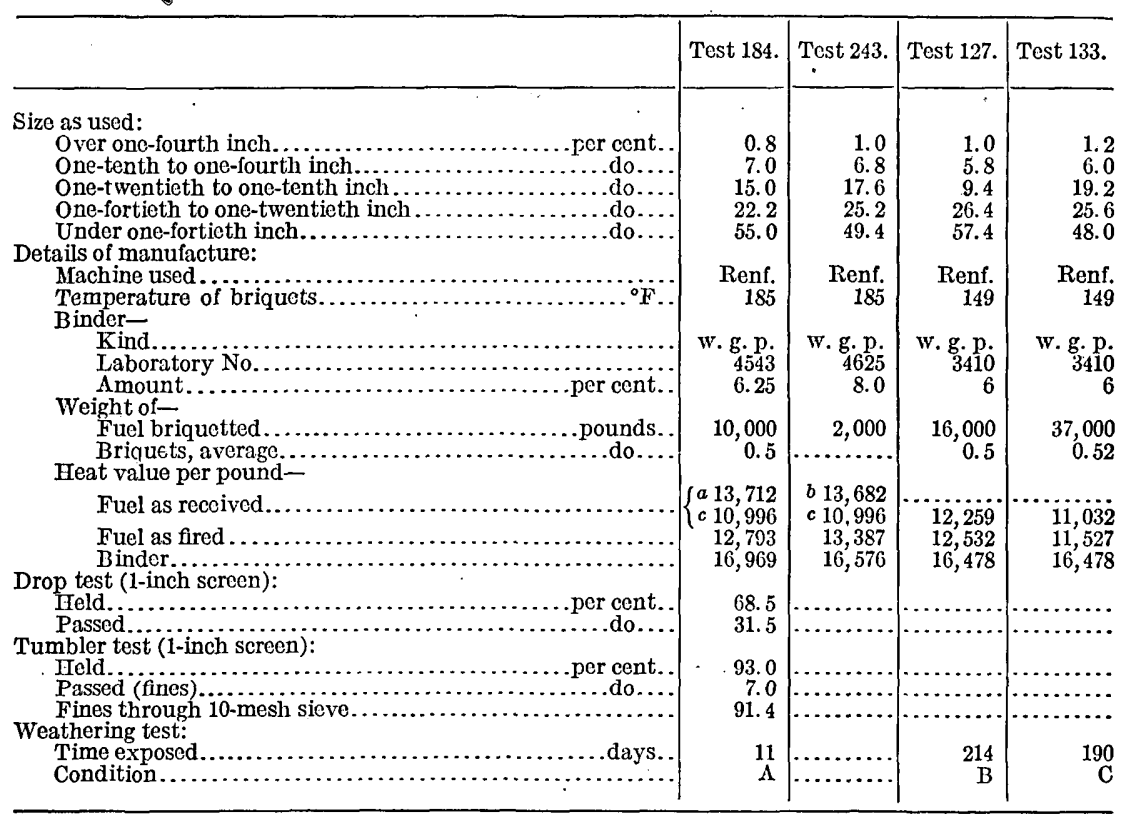

a Pennsylvania No. 15.

$b$ Pennsylvania No. 18.

$c$ Rhode Island No. 1.

In these descriptions Renf. refers to the Renfrow machine; w. g. p. is water-gas pitch; the drop test consisted in dropping 50 pounds of the briquets in a box a distance of $6 \frac{1}{2}$ feet onto an iron plate, screening each time what would go through a 17-mesh wire screen. In the tumbler test 50 pounds were revolved in the Opermayer tum.bler 56 times and then screened through 1-inch and $\frac{1}{10}$-inch mesh screens. Under "Weathering test," A means unchanged; B, shape unchanged, surface pitted or dulled or edges worn; C, outside briquets weathered, fracture not sharp.

House-heating tests were made for briquets described in tests 184 and 243 and steaming tests from briquets made in tests 127 and 133. These have been described under the headings "House heating" and "Steam raising."

\section{BRICK BURNING AND SIMILAR WORK.}

The use of this coal for brick burning or the burning of limestone for fertilizers has been suggested. In this work the broken or fine coal is placed between layers of brick in a kiln or between layers of limestone when burned in piles in the "fields. The writer does not know of such use having been made of the coal and is not prepared to predict how successful it would be. The ash apparently would 
not be a serious detriment in such use. The coal might also be used for the roasting of ores and in other work where the ash is not a serious detriment and high heat rather than long-continued heat is desired.

\section{INDIRECT USE AS WATER GAS OR PRODUCER GAS.}

There has been a widespread feeling for many years that Rhode Island coal would some day come to its own through its use in the production of water gas or producer gas for metallurgic work, or more especially for use in the gas engine in the production of electric power to be used for manufacturing near the mines or to be transmitted to the cities. Its possible use in the manufacture of water gas was mentioned by Shaler in 1899, who says "that a test of a few tons of the coal had been made in the manufacture of water gas and that it was well suited to the purpose." 1 It has been thought that a few plants situated at the mines, by being specially designed and specially manned, would be able to deal with the peculiar characteristics of the coal satisfactorily and thus take advantage of its location in saving transportation costs.

In principle producer gas is made by forcing air through a mass of incandescent coal so controlled that the oxygen of the air finds a surplus of carbon and unites to form carbon monoxide which is combustible and passed off with the nitrogen, which is inert, the product being known as producer gas. In the manufacture of water gas superheated steam is used in place of the air, and the product consists of hydrogen with carbon monoxide instead of the inert nitrogen. Water gas, therefore, yields about twice as many heat units as the same quantity of producer gas or, if enriched, from four to five times as many. Modern practice has tended toward the producer-gas plant as the most efficient method of transforming the power of the coal immediately into electric power, though with Rhode Island coal water gas may prove the better of the two.

A number of tests have been made by the Bureau of Mines on Rhode Island coal in the producer-gas plant. Though it may be conceded that future tests may, and doubtless will, lead to changes in the construction of the producer-gas plant that will more fully adapt it to the peculiar behavior of Rhode Island coal and that with such an improved and specially devised plant better results would be obtained, yet the figures here quoted may be accepted as fairly indicative of the results obtainable with present forms of the producer.

The results of the producer-gas tests are described in Bulletin 13 of the Bureau of Mines, and because of the interest in this phase of the problem the results of the tests are given in full.

1 Shaler, N. S., Woodworth, J. B., Foer: 3 , A. F., Geology of the Narragansett Basin: U. S. Geol. Survey Mon. 33, p. 84, 1899.

$97887^{\circ}-$ Bull. $615-15-4$ 
The coal used in test 113 was mined from the Budlong pit, at Cranston, under the supervision of J. S. Burrows.

The coal for tests 190 and 191 was later shipped from the same pit by Budlong \& Son. It consisted principally of small lumps, 1 or 2 inches in size, and a few larger lumps were broken up by the hammer before firing and the fine material was screened out. Before making this test a little of it was tried in the blacksmith forge with the following result, as described in a preliminary report: ${ }^{1}$

Before the testing was started a small quantity of this fuel was burned in a blacksmith's forge in order to note any special characteristics that it might exhibit while burning, and thus aid in the operation of the producer during the test. On the blacksmith's forge it was very slow to ignite, but when well ignited it burnt very much like anthracite and gave an intense heat. When first fired, it snapped violently and frequently small lumps of coal were thrown forcibly from the fire. After burning for about half an hour in the forge there was a considerable amount of slag or clinker about the consistency of thick tar. Upon examination this slag did not appear to consist entirely of fused ash, but to contain quite a portion of the unburnt fuel in the fused state. Although the conditions in the blacksmith forge of heavy forced draft were unlike the conditions that would exist in the producer, it was expected that the tendency of the fuel to fuse would prevent to some extent its more successful use in the producer.

The coal for test 194, amounting to about 20 tons, was obtained from the Portsmouth mine under the supervision of C. A. Fisher, of the United States Geological Survey. It was taken in the heading at the 800 -foot level, about 1,200 feet south of the slope. At this point the coal was being mined and mining had extended about 50 feet beyond the face of the heading, which had been left when the mine was previously abandoned. The coal at this point, as described by Mr. Brown ${ }^{2}-$

is some 65 inches thick, showing.in the upper and lower portions of the coal bed some 2 or 3 inches of graphitic shaly material, which probably results from shear. The coal shows a considerable degree of purity, excepting near the middle of the bed where $1 \frac{1}{2}$ or 2 inches of "bone" with quartz and later pyrite occur. The bedding is rather thin, probably one-half inch, but in some cases there is a thick bed of some 8 inches of massive coal. Throughout the bed, increasing toward the edges of the roll, there occur numerous offset veins of quartz, sometimes reaching a thickness of 2 or 3 inches, but penetrating, in a large number of cases, in mere shreds and veinlets of silica. *** No run-of-mine coal could be taken and the tests therefore are made upon the best coal that the mine can produce.

The tests are described as follows: ${ }^{3}$

Rhode Island No. 1, test 119.- Rhode Island No. 1 was a graphitic coal having a gray, metallic appearance. Some of the lumps were extremely hard, but others were soft. This material was charged on top of a good fuel bed of Tennessee coal capable of making a gas of average quality. As the charging continued, the heat value of the

1 Preliminary report of the natural resources survey of Rhode Island: Rhode Island Bur. Industrial Statistics Bull. 1 (Ann. Rept. 1909, pt. 3), p. 105, 1910.

2 Idem, pp. 95-96.

3 Bur. Mines Bull. 13, pp. 199, 342-346, 349, 1911. 
gas steadily decreased, whereas the temperature of the fuel bed increased. After 15 hours the calorimeter would not work because of the low-heat value of the gas, which, at that time, was about 55 British thermal units per cubic foot. Three hours later the engine stopped and subsequent attempts to start it again were unsuccessful.

$$
\text { * }
$$
* * * *

Pittsburgh No. 19A, test 190.-The fuel used during this test was a Rhode Island graphitic anthracite. It was heavy and hard and a freshly broken surface presented a glossy appearance; it contained a large percentage of graphite and one could mark with pieces of the coal as readily as with a pencil.

Because this fuel ignited slowly the coke bed was allowed to become thoroughly incandescent before any of the graphitic coal was charged, and while the fuel bed was being built up a maximum draft was maintained. About an hour after the first charge of coal was made the gas burned steadily at the test cock, and although it was low in heat value the engine was started. After running about 30 minutes, however, on no load it stopped, due to the poor quality of the gas. After the engine was started the draft in the producer decreased considerably on account of the small amount of gas consumed by the engine. With this reduced draft the fire died down and the gas decreased rapidly in heat value. Soon after the engine stopped the gas was discharged into the atmosphere, and with a good draft the fire soon began to improve; the gas, however, was of unsatisfactory quality for some time. The engine was finally started again, and in order to maintain a sufficient draft to produce combustible gas a portion of the gas was allowed to escape through the purge pipe. During the remainder of the day (about $1 \frac{1}{2}$ hours) the producer gave no trouble and a little over half of full load was maintained at the engine. At the close of the day's run the producer was seemingly in good condition for the night's shutdown. The fire, however, did not keep and the next morning it was necessary to rekindle it with wood. As is shown by the graphic $\log$, the results obtained were more satisfactory after the first day's trial. From one to two hours each morning were required to get the producer in condition to generate gas of sufficient heat value to start the engine, and at the close of each day's run the fire was banked with a good grade of coal in order to hold it overnight. Throughout the greater part of the test also a considerable portion of the gas was necessarily allowed to escape to the atmosphere in order to maintain the required draft. The quantity of gas thus wasted was difficult to estimate, and for this reason little value can be attached to the figures given in the table on page 357 [p. 53 of this paper] for fuel consumed per horsepower hour, since no allowance for this waste was made.

Throughout the test the fuel bed increased rapidly in thickness, and at the end of the fourth day the producer was completely filled with fuel and refuse. One of the characteristics of this graphitic coal is that its ash occupies nearly the same volume as the original fuel. The resistance of the fuel bed was not excessive at any time and few shots were made. Throughout the run little trouble was experienced from clinker, although a considerable quantity formed andoadhered firmly to the producer walls.

Pittsburgh No. 19A, test 191.-A second test was made on Pittsburgh No. 19A in an attempt to reduce the waste of gas and thus obtain results that would be of more value than those obtained from test 190. Instead of kindling a fire on the coke bed, as in the preceding tests, 1,000 pounds of the graphitic coal, making a layer 1 foot thick, were first charged on top of the coke in the producer, and then the fire was started on top of this. The result of this change of procedure was satisfactory; gas of sufficient heat value to run the engine was generated in about an hour and a quarter from the time of starting the fire, and at the end of the test practically all of the coke was recovered. During the first three hours of the test no gas was discharged into the atmosphere, and consequently there was no waste; but at the end of this period the fire began to die out and the gas diminished in heat value. It was evident that the draft in the 
producer was too low; consequently a portion of the gas was allowed to escape, and soon afterwards the fuel bed was in much better condition and the heat value of the gas was considerably higher.

Throughout the test it was frequently necessary to resort to this method of increasing the draft in order to generate gas of sufficient heat value to run the engine. Nevertheless the quantity of gas thus wasted was much less than in the preceding test, and from the results given in the table it may be seen that the fuel consumption was also much less. On the other hand, the effort to operate with a minimum waste of gas resulted in a much lower average draft than in the preceding test, and the effect of this was to lower the heat value of the gas, and consequently to diminish the average load which could be carried at the engine.

The thickness of the fuel bed increased rapidly, as in the preceding test, but during the last part of the run there was much more clinker formed than at any time during test 190 .

Pittsburgh No. 62, test 194.-Pittsburgh No. 62 was a graphitic anthracite from Rhode Island, having the same characteristics as Pittsburgh No. 19A. It behaved in a similar manner in the producer, being slow to ignite and requiring a good draft to generate a gas of fair quality. As in previous tests with this fuel, a part of the gas was wasted during much of the time, and for this reason little value can be attached to the figures for fuel consumption per brake horsepower-hour given in the table on page 357 [p. 53 of this paper]. This graphitic coal would not hold fire overnight in the producer, and in order to avoid rekindling each morning the fire was banked at the end of each day's run with a good grade of bituminous coal, which held the fire satisfactorily. The coal thus used was reduced to its equivalent weight of graphitic coal and charged against the test. From $1 \frac{1}{2}$ to 2 hours each morning, after starting the producer, was required before a gas capable of running the engine was generated. Throughout the test the gas was rather variable in quality and the load carried was somewhat irregular, as is shown by the graphic log. A comparatively small amount of clinker formed during this run.

Results of producer-gas tests made at Pittsburgh, Pa.

\begin{tabular}{|c|c|c|c|}
\hline$\because \quad-$ & $\begin{array}{l}\text { No. 19A, } \\
\text { Auburn, } \\
\text { R. I. }\end{array}$ & $\begin{array}{c}\text { No. } 19 A, \\
\text { Auburn, } \\
\text { R. I. }\end{array}$ & $\begin{array}{l}\text { No. } 62 \text {, } \\
\text { Ports- } \\
\text { mouth, } \\
\text { R. I. }\end{array}$ \\
\hline 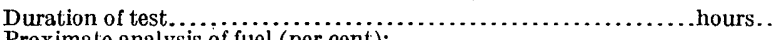 & 22.33 & 29.00 & 32.17 \\
\hline Proximate analysis of fuel (per cent): & & & \\
\hline $\begin{array}{l}\text { Moisture } \ldots \ldots \ldots \ldots \ldots \ldots \\
\text { Volatile matter................ }\end{array}$ & $\begin{array}{l}3.70 \\
2.11\end{array}$ & $\begin{array}{l}4.80 \\
2.50\end{array}$ & $\begin{array}{r}11.50 \\
3.41\end{array}$ \\
\hline Fixed carbon.. & 71.45 & 69.90 & 63.59 \\
\hline 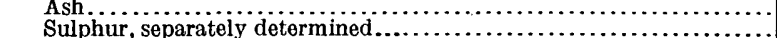 & $\begin{array}{r}22.74 \\
.06\end{array}$ & $\begin{array}{r}22.80 \\
.10\end{array}$ & $\begin{array}{r}21.50 \\
.59\end{array}$ \\
\hline $\begin{array}{l}\text { Fuel charged in producer (pounds): } a \\
\text { Total- }\end{array}$ & .00 & .10 & .09 \\
\hline As fired.................. & 11,335 & 9,454 & 11,334 \\
\hline 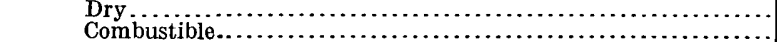 & $\begin{array}{r}10,916 \\
8,339\end{array}$ & $\begin{array}{l}9,000 \\
6,844\end{array}$ & $\begin{array}{r}10,031 \\
7,594\end{array}$ \\
\hline Per hour- & & & \\
\hline As fired. & 507.6 & 326.0 & 352.3 \\
\hline Dry... & 488.8 & 310.3 & 311.8 \\
\hline Per square foot of fuel-bed area per hour-. & $3 / 3.7$ & 236.0 & 236.1 \\
\hline 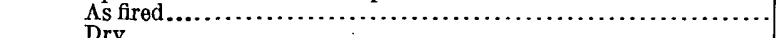 & 39.2 & 25.2 & 27.2 \\
\hline 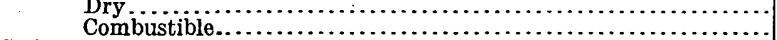 & $\begin{array}{l}37.7 \\
28.8\end{array}$ & $\begin{array}{l}24.0 \\
18.2\end{array}$ & $\begin{array}{l}24.1 \\
18.2\end{array}$ \\
\hline Refuse: & & & \\
\hline $\begin{array}{l}\text { Total (determined by weight). } \\
\text { Combustible in refuse- }\end{array}$ & 3,000 & 2,138 & 2,815 \\
\hline $\begin{array}{l}\text { Total } \ldots \ldots \ldots \ldots \ldots \ldots \ldots \ldots \\
\text { Per cont } \ldots \ldots \ldots \ldots \ldots \ldots \ldots \ldots\end{array}$ & $\begin{array}{r}1,648 \\
55.0\end{array}$ & $\begin{array}{r}845 \\
39.5\end{array}$ & $\begin{array}{r}551 \\
55.1\end{array}$ \\
\hline
\end{tabular}

a Figures given include the fuel equivalent of coke consumed during test. 
Results of producer-gas tests made at Pittsburgh, Pa.-Continued.

\begin{tabular}{|c|c|c|c|}
\hline & $\begin{array}{l}\text { No. } 19 \mathrm{~A}, \\
\text { Aưurn, } \\
\text { R. I. }\end{array}$ & $\begin{array}{l}\text { No. } 19 \mathrm{~A}, \\
\text { Auburn, } \\
\text { R. I. }\end{array}$ & $\begin{array}{l}\text { No. 62, } \\
\text { Ports- } \\
\text { mouth, } \\
\text { R.I. }\end{array}$ \\
\hline Combustible consumed: & & & \\
\hline 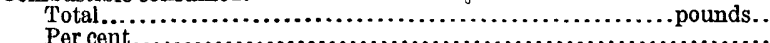 & 6,691 & 5,999 & 6,043 \\
\hline $\begin{array}{l}\text { Per cent................................. } \\
\text { Coke in fixing bed (pounds): }\end{array}$ & 80.2 & 87.7 & 79.6 \\
\hline Total charged in producer. & 813 & 1,017 & 1,435 \\
\hline Recovered from refuse... & 166 & 989 & 673 \\
\hline Consumed during test.. & 647 & 28 & .762 \\
\hline Calorific value (British thermal units & & & \\
\hline 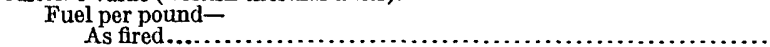 & 10,121 & 10,090 & \\
\hline Dry .............. & $\begin{array}{l}10,121 \\
10,510\end{array}$ & $\begin{array}{l}10,090 \\
10,590\end{array}$ & $\begin{array}{l}10,440 \\
10,523\end{array}$ \\
\hline Combustible..... & 13,759 & 13,930 & 13,898 \\
\hline Standard gas- & & & \\
\hline From 1 pound of fuel- & & & \\
\hline As fired.............. & 2,587 & 3,996 & 3,777 \\
\hline Per cubic foot.... & 2,696 & $\begin{array}{r}4,205 \\
94,7\end{array}$ & 4,262 \\
\hline Consumed per horsepov & & & \\
\hline Indicated........... & 9,296 & 10,076 & 8,989 \\
\hline Brak & 11,258 & 12,548 & 10,757 \\
\hline Electrical.. & 13,319 & 15,010 & 12,625 \\
\hline Equivalent to stated horsepower per minute- & & & \\
\hline Gas... & 21,919 & 21,737 & 22,161 \\
\hline Indicated... & 5,993 & 5,489 & 6,269 \\
\hline Brake......... & 4,950 & 4,407 & 5,238 \\
\hline Electrical..... & 4,187 & 3,682 & 4,462 \\
\hline Standard gas produced (cubic fe & & & \\
\hline Total.. & 296,348 & 399,379 & 423,526 \\
\hline Per hour. & 13,271 & 13,772 & 13,165 \\
\hline f fuel charged- & & & \\
\hline …......... & $\begin{array}{l}20.1 \\
27.2\end{array}$ & $\begin{array}{l}42.2 \\
44.4\end{array}$ & $\begin{array}{l}37.4 \\
42.2\end{array}$ \\
\hline Combustible............. & 35.5 & 58.4 & 55.8 \\
\hline Standard gas consumed by engine ( & & & \\
\hline Per hour.. & 13,261 & 13,762 & 13,155 \\
\hline r hour- & & & \\
\hline ed............. & 93.8 & 106.4 & 89.0 \\
\hline Brake $\ldots . . . \ldots \ldots \ldots \ldots$ & 113.6 & 132.5 & 106.5 \\
\hline Composition of gas (per cent of volume): & & & \\
\hline 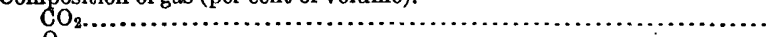 & 6.98 & 7.24 & 5,08 \\
\hline $\mathrm{O}_{2} \ldots \ldots \ldots \ldots \ldots \ldots \ldots \ldots$ & .13 & .06 & .08 \\
\hline $\mathrm{C}_{2} \mathrm{H}$ & .00 & 900 & $94^{.00}$ \\
\hline (n.............. & $\begin{array}{r}23.25 \\
6.33\end{array}$ & $\begin{array}{r}22.74 \\
5.28\end{array}$ & 24.91 \\
\hline $\mathrm{CH}$ & $\begin{array}{r}0.33 \\
.38\end{array}$ & 0.28 & $\begin{array}{l}\text { 4. } \\
.43\end{array}$ \\
\hline $\mathrm{N}_{2} \ldots \ldots \ldots$ & 62.93 & 64.34 & 64.84 \\
\hline Water used: & & & \\
\hline Vaporizer (pounds)- & & & \\
\hline Total.................. & 1,015 & 1,054 & a 153 \\
\hline Per hour............... & 45.5 & 36.3 & ........... \\
\hline $\begin{array}{l}\text { Per pound of fuel fired.. } \\
\text { Wet }\end{array}$ & .09 & .11 & .......... \\
\hline 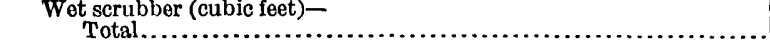 & & & \\
\hline 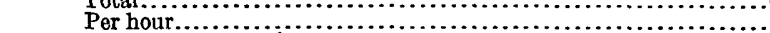 & $\begin{array}{r}696 \\
282\end{array}$ & $\begin{array}{r}4,503 \\
155\end{array}$ & $\begin{array}{l}0,371 \\
167\end{array}$ \\
\hline Per 1,00 & 21.3 & 11.3 & 127 \\
\hline Engine jackets (cubic feet) - & & & \\
\hline (n)................... & 2,557 & 3,382 & 2,866 \\
\hline Per hour.. & 115 & 121 & 89 \\
\hline ower hou & .98 & 1.16 & .72 \\
\hline Entire plant & & & \\
\hline Total.. & 8,869 & 7,902 & 8,239 \\
\hline Per hour & 397 & 273 & 256 \\
\hline Per bra & 3.40 & 2.62 & 2.07 \\
\hline gercury)... & 29.18 & 29.12 & 29.20 \\
\hline $\begin{array}{l}\text { Average pressu } \\
\text { Gas leaving }\end{array}$ & -6.21 & -6.99 & \\
\hline Gas leaving econor & $=0.21$ & $=7.24$ & -5.09 \\
\hline t scrubber... & -10.68 & -10.04 & -7.59 \\
\hline dry scrubber. & +5.55 & +6.04 & +6.14 \\
\hline ter... & +2.97 & +293 & +3.37 \\
\hline Gas leaving meter... & +.62 & +.39 & +1.85 \\
\hline A verage temperatures $\left({ }^{\circ} \mathrm{F}.\right):$ & & & \\
\hline Air entering economizer........ & 110 & 103 & 64 \\
\hline Air and vapor entering produce & 391 & $\begin{array}{r}363 \\
048\end{array}$ & $\begin{array}{r}400 \\
180\end{array}$ \\
\hline $\begin{array}{l}\text { Gas leaving producer........... } \\
\text { Gas leaving economizer....... }\end{array}$ & 1,219 & $\begin{array}{r}1,048 \\
543\end{array}$ & 1,180 \\
\hline
\end{tabular}

$a$ Vaporizer used only in part of test. 
Results of producer-gas tests made at Pittsburgh, Pa.-Continued.

\begin{tabular}{|c|c|c|c|}
\hline & $\begin{array}{l}\text { No. } 19 \text { A, } \\
\text { Auburn, } \\
\text { R. I. }\end{array}$ & $\begin{array}{c}\text { No. } 19 \mathrm{~A}, \\
\text { Auburn, } \\
\text { R. I. }\end{array}$ & $\begin{array}{l}\text { No. 62, } \\
\text { Ports- } \\
\text { mouth, } \\
\text { R. I. }\end{array}$ \\
\hline \\
\hline 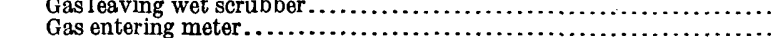 & $\begin{array}{l}81 \\
85\end{array}$ & 80 & 47 \\
\hline Jacket water: & & & \\
\hline Entering & 72 & 76 & 39 \\
\hline 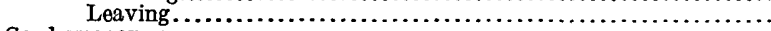 & 137 & 135 & 119 \\
\hline Gas horsepower........................ & 516.8 & 512.5 & 522.5 \\
\hline Revolutions per minute of gas engine & 261.2 & 260.7 & 268.8 \\
\hline Explosions per minute per cylinder.. & 130.6 & 130.4 & 134.4 \\
\hline Indicated horsepower, total........... & 141.3 & 129.4 & 147.8 \\
\hline \multicolumn{4}{|l|}{ Brake horsepower: } \\
\hline $\begin{array}{l}\text { Developed at engine....... } \\
\text { Commercially available... }\end{array}$ & 116. 7 & 103.9 & 123.5 \\
\hline $\begin{array}{l}\text { Commercially available..... } \\
\text { Electrical horsepower: }\end{array}$ & 113.4 & 100.7 & 120.1 \\
\hline Developed at switchboard. & 98.7 & 86.8 & 105.2 \\
\hline Commercially available.... & 95.9 & 84.1 & 102.3 \\
\hline Average electrical horsepower required to rum auxiliary machinery.. & 2.8 & 2.7 & 2.9 \\
\hline \multicolumn{4}{|l|}{$\begin{array}{l}\text { Economic results: Fuel charged in producer per horsepower hour (pounds): } \\
\text { Per indicated horsepower developed- }\end{array}$} \\
\hline 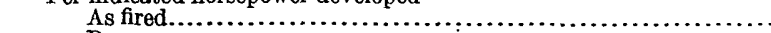 & 3.59 & 2.52 & 2.38 \\
\hline Dry $\ldots \ldots \ldots \ldots \ldots \ldots \ldots$ & 3.46 & 2.40 & 2.11 \\
\hline \multirow{3}{*}{\multicolumn{4}{|c|}{$\begin{array}{l}\text { Per brake horsepower- }- \\
\text { Developed at engine- }\end{array}$}} \\
\hline & & & \\
\hline & & & \\
\hline As fired....... & 4.35 & 3.14 & 2.85 \\
\hline 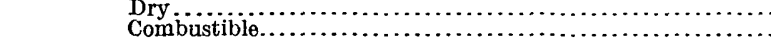 & 4.19 & 2.99 & 2.52 \\
\hline \multicolumn{4}{|l|}{ lly available- } \\
\hline As fired. & 4.48 & 3.24 & 2.93 \\
\hline Dry $\ldots \ldots \ldots \ldots \ldots$ & 4.31 & 3.08 & 2.60 \\
\hline Combustible............ & 3.29 & 2.34 & 1.97 \\
\hline \multicolumn{4}{|l|}{ Per electrical horsepower- } \\
\hline \multicolumn{4}{|l|}{ Developed at switchboard- } \\
\hline As fired................... & & & 3.35 \\
\hline Dry & 4.95 & 3.57 & 2.96 \\
\hline Combustible........... & 3.78 & 2.72 & \\
\hline \multicolumn{4}{|l|}{ Commercially available- } \\
\hline As fired............... & 5.29 & 3.88 & 3.44 \\
\hline (..................... & 5.10 & 3.69 . & 3.05 \\
\hline Combustible............. & 3.89 & 2.81 & 2.31 \\
\hline \multicolumn{4}{|l|}{ Efficiency (per cent): } \\
\hline Of conversion and cleaning gas.:. & 25.6 & 39.7 & 36.2 \\
\hline 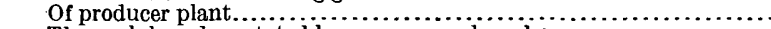 & 25.5 & 39.4 & 36.0 \\
\hline \multicolumn{4}{|l|}{ Thermal, based on stated horsepower and gas horsepower- } \\
\hline Indicated..................................... & 27.3 & 25.3 & 28.3 \\
\hline Brake. & 22.6 & 20.3 & 23.6 \\
\hline Electrical................... & 19.1 & 16.9 & 20.1 \\
\hline Of entire plant, based on fuel charged per stated horsepower per hour- & & & \\
\hline Brake horsepower developed at engine. & 5.8 & 8.0 & 8.6 6 \\
\hline Brake horsepower commercially available.. & 5.6 & 7.8 & 8.3 \\
\hline Electrical horsepower developed at switchboard.. & 4.9 & 6.7 & 7.3 \\
\hline Electrical horsepower commercially availahle.... & 4. 8 & 6.5 & 7.1 \\
\hline
\end{tabular}

In order that comparison may be made with the results of tests of other coals there is given a supplementary table, ${ }^{1}$ showing the pounds of fuel of Rhode Island and some other coals charged in the producer per commercial brake horsepower and electric horsepower, as that forms the best basis for comparison. 
UTIIIZATION OF THE COAL.

\begin{tabular}{|c|c|c|c|c|}
\hline \multirow{6}{*}{\multicolumn{2}{|c|}{0}} & \multirow{3}{*}{ 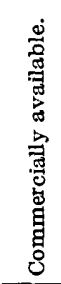 } & 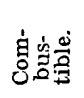 & 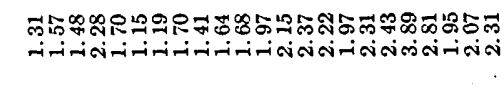 \\
\hline & & & 官 & 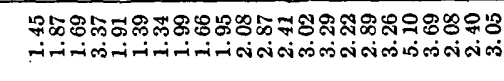 \\
\hline & & & 的它 & 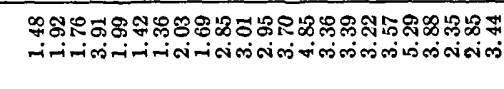 \\
\hline & & \multirow{3}{*}{ 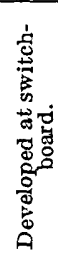 } & 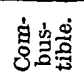 & 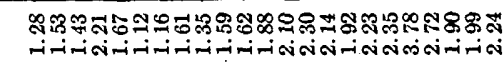 \\
\hline & & & $\dot{\vec{A}}$ & 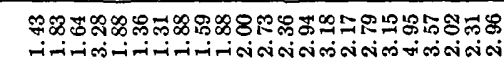 \\
\hline & & & 舟要 & 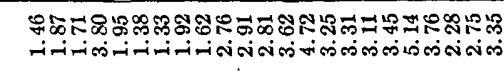 \\
\hline \multirow{6}{*}{\multicolumn{2}{|c|}{ 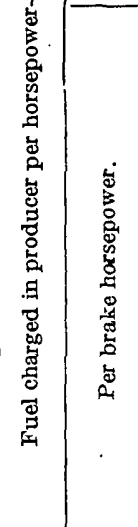 }} & \multirow{3}{*}{ 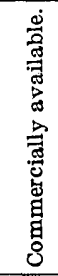 } & 戛的高 & 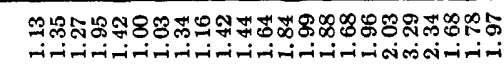 \\
\hline & & & 宫 & 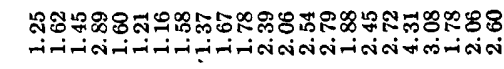 \\
\hline & & & 㖇 & 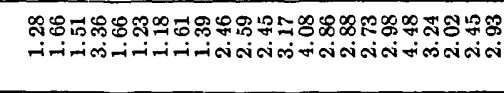 \\
\hline & & \multirow{3}{*}{ 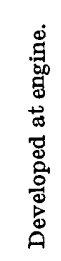 } & 岁寄言 & 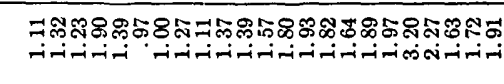 \\
\hline & & & 宫 & 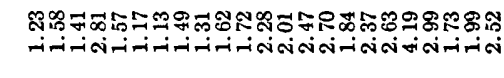 \\
\hline & & & భ串 & 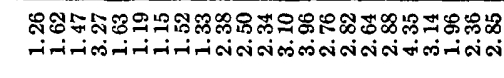 \\
\hline \multirow{3}{*}{\multicolumn{2}{|c|}{ 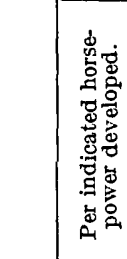 }} & \multicolumn{2}{|c|}{ घ่ } & 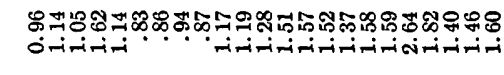 \\
\hline & & \multicolumn{2}{|c|}{ s } & 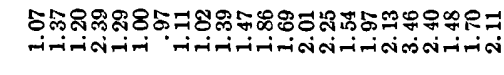 \\
\hline & & \multicolumn{2}{|c|}{ 禹良 } & 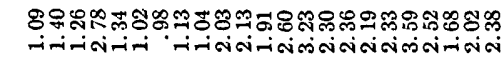 \\
\hline & & \multicolumn{2}{|l|}{ 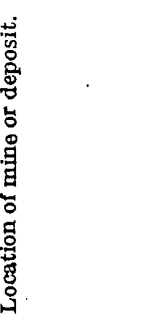 } & 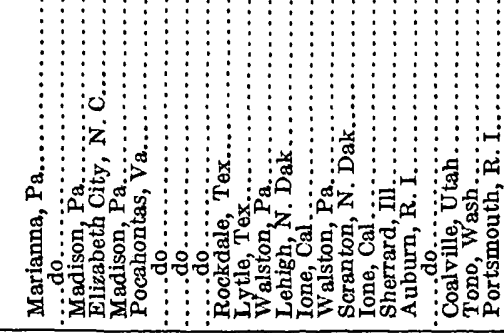 \\
\hline & & \multicolumn{2}{|l|}{ a. } & 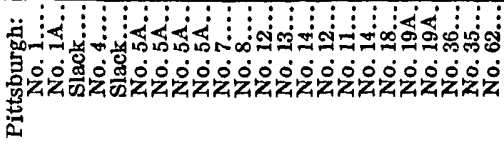 \\
\hline & & \multicolumn{2}{|l|}{ 莺宫 } & 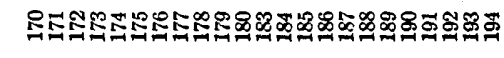 \\
\hline
\end{tabular}


In general, a study of the full tables as published in Bulletin 13 of the Bureau of Mines shows that it requires from 1 to 2 pounds of Pocahontas coal or bituminous coal from central Pennsylvania to produce 1 available electric horsepower-hour as compared with 2.85 to 5.29 pounds of Rhode Island coal. This may be stated differently as follows: One ton of Pocahontas coal or central Pennsylvania bituminous coal will yield 1,000 to 2,000 available horsepower-hours, whereas Rhode Island coal, according to the tests made, will yield from 375 to 700 horsepower-hours. Generally, the yield from Rhode Island coal appears to have been about one-third of that from the other coals named. If account be taken of the cost and interest for transmission lines from the field to centers of distribution, as from Portsmouth to Providence, and the added cost of handling the larger quantity of coal necessary and the very much larger quantity of ash, it appears that Rhode Island coal at the mouth of the mine for use in the producer-gas plant, is worth only one-fourth to one-third the value of competing coals delivered at Providence or Boston. If it be assumed, however, that specially designed apparatus would prevent the loss of gas noted in the experiments it seems possible that from 2 to 3 pounds of Rhode Island coal could be made to produce 1 electric horsepower-hour, averaging say $2 \frac{1}{2}$ pounds, against an average of, say, $1 \frac{1}{2}$ pounds for competing steam coals. With the added costs referred to above, it seems that a ton of average selected Rhode Island coal should deliver in Providence or Boston electric power equivalent to that obtained from one-half ton of average competing coals.

In November, 1913, Pocahontas coal was selling at wholesale in Providence and Boston at a little under $\$ 4$ a ton. In order to compete with power produced by that coal, Rhode Island coal of the best grade must be mined and delivered at the mouth of the mine to a producer-gas plant for not over half that price, or $\$ 2$ a ton.

In using Rhode Island coal in the producer-gas plant, the cost of mining might be reduced sufficiently to allow competition by putting the producer-gas plant in the mine, as low in the basin as possible. As the coal carries no combustible volatile matter, neither the coal nor the dust should offer any danger of fire or explosion and, as the rocks adjacent to the coal are very firm, the cost of preparing rooms should be little more than the cost of excavation. Such rooms are now used for pumps in the Portsmouth mine. By placing the plant low the coal can be lowered by gravity from the higher levels. The plant could also be installed in small movable units, including a gas producer and gas engine, the power to be taken out of the mine as electricity. By this method it might prove feasible to move the unit plants from one of these large lenses to another. As these lenses in the Portsmouth mine and at Cranston appear to 
have, in places, a length of 1,000 feet or more and a width of 100 or 200 feet or more and, at Portsmouth, an average thickness of $4 \frac{1}{2}$ feet, it seems that one of them should yield sufficient tonnage to cover the cost of moving and installation of a small unit. Whether such a mine installation, by eliminating the cost of the lift out of the mine, would reduce the total cost sufficiently to render competition possible would have to be demonstrated.

\section{USE FOR FOUNDRY FACINGS AND FURNACE IININGS.}

In the preceding sections the utilization of Rhode Island anthracite has been discussed. This has been the specific purpose of this bulletin. A little may, however, be said in regard to the use of the more graphitic portions of the beds. Though all the anthracite contains more or less graphite, portions of the beds have been changed entirely to what appears to be graphite. Such a bed at Fenners Ledge is being mined at present in an open cut by Mr. Fenner and sold for foundry facings, for which it appears to be well adapted after the proper preparation. At the old Gross mine, to the south, an attempt was made to prepare the graphite for market. Buildings were erected and machinery installed. The graphite was crushed and screened, using expensive brass sieves. The process adopted did not prove successful, apparently owing to the difficulty of separating the fine quartz.

Graphite has also been mined at Bridgeton, Valley Falls, and Tiverton, at the first and last places from open cuts, but at Valley Falls the workings were extended underground." The material was used for foundry facings and some of it for furnace linings.

\section{CONCLUSIONS.}

A review of the physical and chemical character of Rhode Island coal, the history of its past exploitation and use, and past and recent tests of its use leads to the following general conclusions:

Rhode Island coal is a high-ash, high-moisture, graphitic anthracite coal of high specific gravity.

Calorimeter tests show it to yield from 6,000 to 11,000 British thermal units, averaging, as taken from the mine, about 9,000 British thermal units, or about 10,000 after air drying. As compared with coals shipped to New England, with which it must compete, which range from 12,000 British thermal units for Pennsylvania anthracite culm to nearly 15,000 British thermal units, and average 13,000 for anthracite and about 14,500 for bituminous as mined, Rhode Island coal yields on the average from 60 to 70 per cent of the heat value of these competing coals. The best of the Rhode Island coal may reach 90 per cent of the heat value of the poorest competing coal and 80 per cent of the better grade. 
A careful test in actual practice showed Rhode Island coal to have 72 per cent of the efficiency of Lackawanna coal.

In experimental tests by the Bureau of Mines, Rhode Island coal yielded from 54 to 68 per cent as much horsepower as the other coals listed and from 48 to 60 per cent as many pounds of water evaporated per pound of fuel.

In household and steam use it is found to ignite slowly and with difficulty and to make so hot a fire as to destroy stove tops, melt vessels and boilers placed on it, and destroy furnace linings, so that the fire is difficult to maintain and control. Its ignition and burning are improved by breaking down to small sizes and careful screening.

Rhode Island coal has been successfully used in the metallurgy of copper and iron. Evidence is lacking to show that it could compete with coke in the modern furnace.

Rhode Island coal has been briquetted, but without commercial success. It is believed that future tests may make possible the production of briquets that hold together and do not smoke.

The high specific gravity renders washing of this coal with present methods difficult if not impossible.

In producer-gas tests by the Bureau of Mines, Rhode Island coal yielded from 375 to 700 horsepower-hours per ton of coal, as compared with 1,000 to 2,000 available horsepower-hours for competing coals. Specially designed plants, it seems reasonable to suppose, might be made to yield at least one-half as much power with Rhode Island coal as with competing coals.

In general, it appears that at the present time the best outlook for Rhode Island coal is in the production of electric power at the mines, either in steam engines or by means of specially devised producer-gas or water-gas plants. It appears further, however, that this can not be done with financial success until it can be shown that Rhode Island coal can be mined and delivered at the furnace for less than one-half the wholesale price of competing coals in Providence and Boston.

\section{PAPERS AND REPORTS.}

Papers and reports to which reference is made or which are of value in connection with this subject are listed below in chronologic order:

1. Providence Journal. Through the kindness of officials of the Providence Public Library, the writer had access to the old files of the Journal and to a large number of clippings on the subject of Rhode Island coal. These have formed the basis of much of the section on the history of development (pp. 7-14).

2. Hearing on the memorial of the New England Coal Mining Co. before the select special committee of the General Assembly of Rhode Island and Providence Plantations, together with the report of the committee, 1838.

3. Report and bill to the Commonwealth of Massachusetts relating to the coal mines of the State, 1839. 
4. Jackson, C. T., Report on the geologic and agricultural survey of the State of Rhode Island, Providence, 1840.

5. Hitchcock, E. T., Final report on the geology of Massachusetts, Northampton, 1841.

6. Mount Hope Coal Co., The coal beds of Rhode Island, 1852.

7. Hitchcock, E. T., The coal field of Bristol County and of Rhode Island: Am. Jour. Sci., 2d ser., vol. 16, pp. 227-336, 1853.

8. Hitchcock, E. T., Geology of the Island of Aquidneck: Proc. Am. Assoc. Adv. Sci., vol. 14, pp. 112-137, 1860.

9. Rhode Island Society for the Encouragement of Domestic Industry, Providence, 1869.

10. Memorial of T. S. Ridgway, in relation to the coal field of Rhode Island, presented to the General Assembly, 1870.

11. Emmons, A. B., Notes on the Rhode Island and Massachusetts coals: Am. Inst. Min. Eng. Trans., vol. 13, pp. 510-517, 1885.

12. Adams, W. H., Eng. and Min. Jour., 1886. (Referred to as having described some tests on Rhode Island coal; could not be located.)

13. Providence Franklin Society. Report on the geology of Rhode Island, Providence, 1887. (Gives a complete list of papers on the geology of Rhode Island up to the time of publication.)

14. Shaler, N. S., Wood worth, J. B., Foerste, A.F., Geology of the Narragansett Basin: U. S. Geol. Survey Mon. 33, 1899. (This is a complete comprehensive report on the geology of the coal basin containing the Rhode Island coal. It does not deal at great length with the coal from either the stratigraphic or the commercial standpoint.)

15. Second Geol. Survey Pennsylvania Summary Rept., vol. 3, pt. 1, 1895.

16. Lord, N. W., Experimental work conducted in the chemical laboratory of the United States fuel-testing plant at St. Louis, Mo.: U. S. Geol. Survey Bull. 323, 1907.

17. Breckenridge, L. P., A study of four hundred steaming tests, made at the fueltesting plant, St. Louis, Mo.: U. S. Geol. Survey Bull. 325, 1907.

18. Holmes, J. A., in charge, Report of the United States fuel-testing plant at St. Louis, Mo.: U. S. Geol. Survey Bull. 332, 1908.

19. Burrows, J. S., Mine sampling and chemical analyses of coals tested at the United States fuel-testing plant, Norfolk, Va.: U. S. Geol. Survey Bull. 362, 1908.

20. Randall, D. T., Tests of coal and briquets as fuel for house-heating boilers: U. S. Geol. Survey Bull. 366, 1908.

21. Snodgrass, J. M., Fuel tests of house-heating boilers: University of Mllinois Bull. $31,1909$.

22. Preliminary report of the natural resources survey of Rhode Island: Rhode Island Bur. Industrial Statistics Bull. 1 (Ann. Rept. 1909, pt. 3), 1910.

23. Fernald, R. H., and Smith, C. D., Résumé of producer-gas investigations: Bur. Mines Bull. 13, 1911.

24. Lord, N. W., and others, Analyses of coal in the United States: Bur. Mines Bull. 22, 1913.

Brief references were made in the Engineering and Mining Journal and other journals and papers given in the list published in item 13. 
$\int_{1}^{\cdots}$

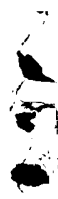

.

$\dot{-}$

N.
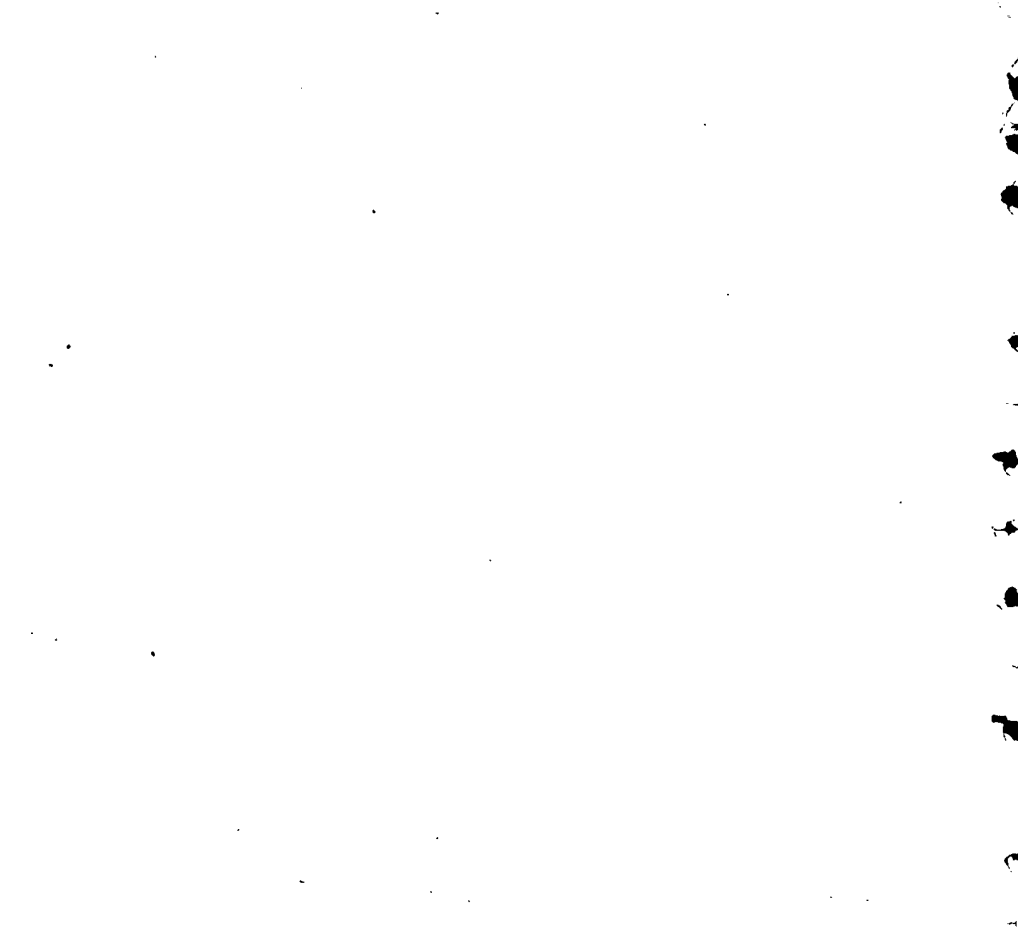

$-$

$-$ 


\section{INDEX.}

A.

Analyses of coals used in briquets............ Page. of Rhode Island anthracite......... 26-29,44

Aquidneck Coal Co., operations of . ........ 8, 9,10

$\Lambda$ sh, cause of high content of ............. 19 determinations of................... 21-22 percentage of . . . . . . . . . . . . . . . . . 23-33

B.

Bibliography 58-59

Blackstone Coal Co., operations of

Brick burning, possible use of the coal for.... 48-49

Briquets, attempts to make............. 13 tests of ................. 40-41,43-45,46-48

Bryant, W. C., cited..................... $\quad 39$

Budlong mine, anthracite in, diagram showing thickness of

face of bed north of mouth of slope, plate showing.

north end of, plate showing..............

open cut in, plate showing...............

operation of ..........................

surface plant at, plate showing...........

Bureau of Mines, briquetting tests by ....... 46-48 steaming tests of various coals by....... 45-46 tests of the coal in a producer-gas plant by $49-57$

\section{C.}

Chemical character of the coal.

Clay, test of desirablo....

Compressed Coal Co., operations of

Cranston coal, briquetting tests of..... 43-45, 46-48

mining of............................ 14

producer-gas tests of................. 50-57

steam test of ....................... 42-43

Cranston Coal Co., operations of ........... 12

Cumberland, coal found in................. 8

D.

Drilling, results of

Durfee, W. F., interest revived by.

\section{E.}

Electricity, use of coal for

Emmons, A. B., cited. 37-38

F.

Fenner Ledge, mining at. graphito mine at, view in.

Foundry facings, use of graphite for G.

Gas producer, ad vantage of placing, in mine. 56-57 Graphite, content of...................... 20 Fenner Ledge, analyses of . ........... 33 produced from coal by heat............. 18-19 uses of. r.

Page.

Heat value, low, reason for .............. 33-37

Heating power, chart showing............ $\quad 24$

comparison of . ...................... 32

Eousehold use of the coal................ 39-41

L. $\quad$

Lackawanna coal, ash in.................. $\quad 29$

comparison of, with Cranston coal...... 42-43

heating power of..................... 35

Lenses, irregular, formed by pressure....... 18

Lime burning, possible use of the coal for.... 48-49

Lotteries granted to aid in mining coal...... 7,8

\section{M.}

Mansfield, Mass., analyses of coals from...... coal mining at.........................

Mansfield Coal Co., operations of .............

Mansfield Mining Co., operations of.......... 9

Massachusetts Mining Co., operations of..... 9

Metallurgy, use of the coal in............10,11.46

Mining, cost of, conditions affecting......... 14-17

Mitchell, Thomas, operations of........... 12

Moisture, behavior of coal toward......... 32, 37-38 percentage of ...................... 23-33

Mount Hope Mining Co., operations of....... 10

N.

Now England Coal Mining Co., operations of. 8-9 New York Carbon Iron Co., operations of.... 11

Newport County coals, analyses of.......... 26

Nichols, Purton, mines opened by .......... 7

$P$.

Pennsylvania, analyses of coals from........ 30

Physical character of the coal............. 20-21

Pocahontas coal, heating power of . ......... 34-35

Pocasset Coal Co., operations of............ 10

Porter, J. B., and Durley, R. J., cited...... 22

Portsmouth coal, analyses of . . . . . . . . . . 28, 29

behavior of, toward moisture......... 37-38

producer-gas test of ................. 50-57

Portsmouth Coal Co. of 1847 , operations of... 9

Portsmouth Coal Co. of 1912, North and South mines of, equipment of .......... 14

operations of ....................... 14

South mine of, plate showing surface plant at.......................... 13

Pressure, effects of, on the coal . . . . 6, 14-15, 17-19 regional differences of................. 19

Producer gas, tests of the coal for.......... 49-57

Providence County coals, analyses of....... 27

Providence Waterworks, test of coal at..... 10-11

Pyrite, content of .................... 20,21

Q.

Quartz, content of..................... 20,21

Quartz veins, formation of.............. 19 
R.

Revolutionary War, use of coal during.......

Rhode Island coal, character of ......... 5-6,57-58 compared with other coals when used in a producer-gas plant . 55-56 history of....................... 7-9,9-14 proper and improper modes of using.... 6-7, 10 Rhode Island Coal Co. of 1809, operations of. Rhode Island Coal Co. of 1810 , operations of. Rhode Island Coal Co. of 1909, operations of. 13-14 Rhode Island coal field, sketch map of....... Roger Williams mine, working of.

\section{S.}

Snodgrass, J. M., cited. Specific gravity, determinations of

Standish, Miles, operations of..

Steam raising, use of the coal in.

\begin{tabular}{r|} 
Page. \\
7 \\
$57-58$ \\
$55-56$ \\
$-9,9-14$ \\
$6-7,10$ \\
8 \\
9 \\
$13-14$ \\
6 \\
11
\end{tabular}

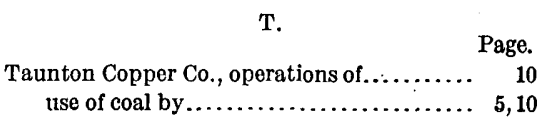

U.

Uses, practicable, of Rhode Island coal..... 38-39

V.

31

W.

Water gas, possible use of the coal for....... $\quad 49$

West Virginia, analyses of coals from......, 31

Worcester Steel Works, operations of....... 12

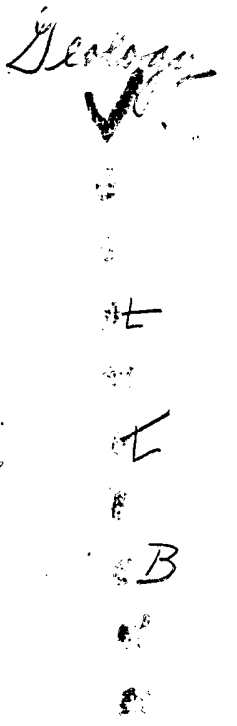

